\title{
فاعلية إستراتيجية القراءة التفسيرية باستخدام الوسائط المتعددة في إتقان التلاوة والتصصيل في تدريس وحدة هن القرآن الكريم لدى طلاب الصف السادس الابتدائي
}

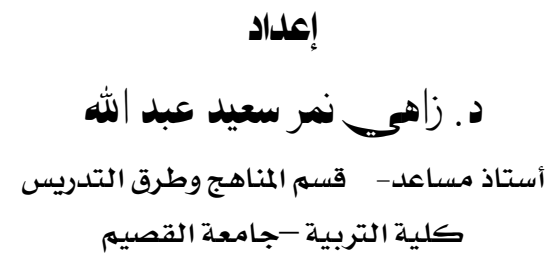

مجلة بحوث التربية النوعية - جامعة المنصورة

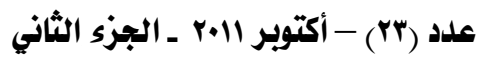




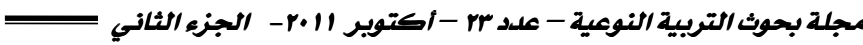

فاعلية إستراتيجية القراءة التفسيرية باستخدام الوسائط المتعددة

في إتقان التلاوة والتصصيل في تدريس وحدة هن القرآن الكريم

لدى طلاب الصف السادس الابتدائي

إعداد

د د زاهيمُرسعيد عبد اللهُ

\section{هلذص الدراسة}

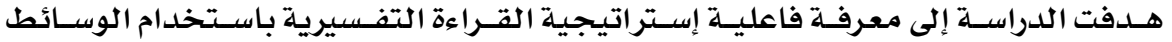

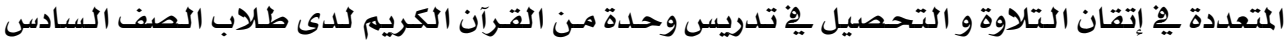

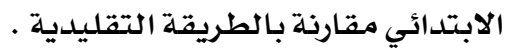

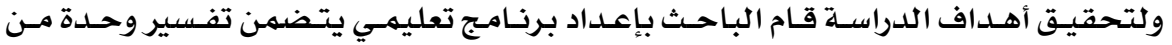

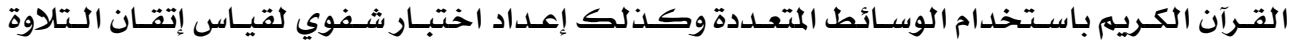

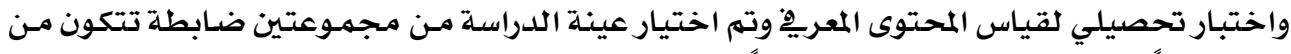

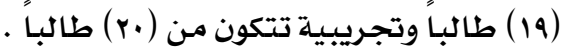

وبعد تطبيق الدراسة على عينة البحث واستخراج المتوسطات الحسابية والانحرافات المعيارية

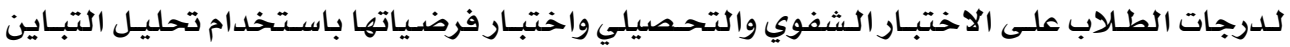

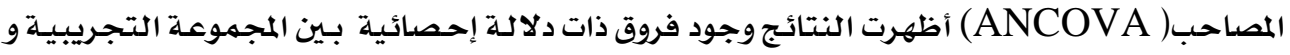

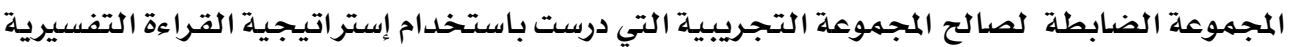

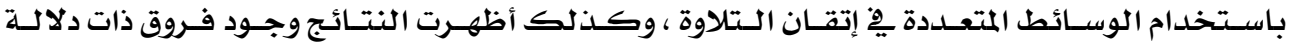

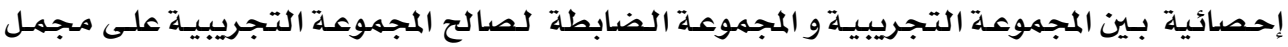

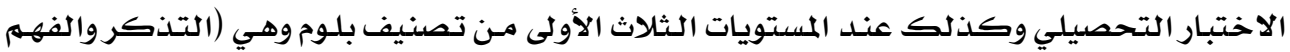

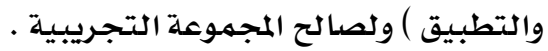

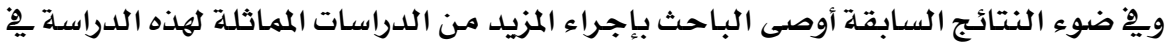

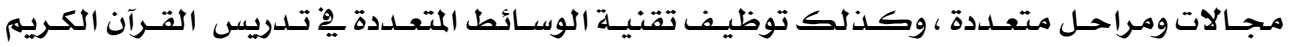

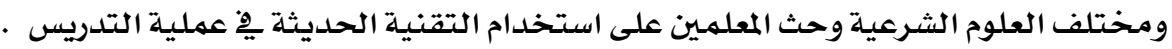

أستاذ مساعد- قسم المناهجج وطرق التدريس - كلية التربية - جامعة القصيم 


\title{
THE EFFECTIVENESS OF STRATEGY INTERPRETATIVE READING USING MULTIMEDIA ON MASTERING AL-TILAWH AND TEACHING IN THE TEACHING UNIT OF HOLY QURAN FOR SIX GRADE PRIMARY
}

\section{Dr.Zahe Nimer Saeed Abdullah}

\begin{abstract}
The aim of study find out the effectiveness of reading strategy interpretative using multimedia in reading proficiency and achievement in teaching units of the Holy Quran to the sixth grade students compared to the traditional method.

To achieve the objectives of the study, the author prepared an educational program includes an interpretation of one unit of Holy Quran using multimedia as well as preparing of an oral examination to measure the mastery of reading also an achievement test to measure knowledge content was chosen as a sample study of two groups control group consisting of (19) students and the experimental group (20 students).

After the application of the study sample and extract the averages and standard deviations for the scores of students on the test and oral grades and test hypotheses using analysis of variance associated with ((ANCOVA)) results, it was found that there were statistically significant differences between the experimental group and control group, for the experimental group which studied the use of strategic reading explanatory using the media multi-master reading, as well as the results showed that there were statistically significant differences between the experimental group and control group for the experimental group on the overall achievement test, as well as at the levels of the first three of Bloom's Taxonomy, namely, (remembering, understanding and application) for the experimental group.

According to the previous results the author recommended further studies similar to this study in the areas of multiple phases, as well as the employment of multimedia technology in teaching of Qoran and the various forensic science and urged teachers to use modern technology in the teaching process.
\end{abstract}




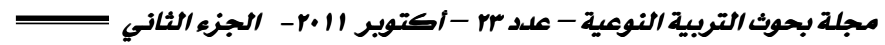

فاعلية إستراتيجية القراءة التفسيرية باستخدام الوسائط المتعددة التهرية

في إتقان التلاوة والتصصيل في تدريس وحدة من القرآن الكريم

لدى طلاب الصف السادس الابتدائي

إعداد

* د ز زاهيمُرسعيد عبد الله

الاقدهمة

جاء القرآن الكريم ليكون منهج حياة وشريعة إنسانية يهـدي النـاس للتي هي أقوم ويقودهم

نحو تحقيق الأمن والسعادة والرقي يِّاء الدنيا والآخرة.

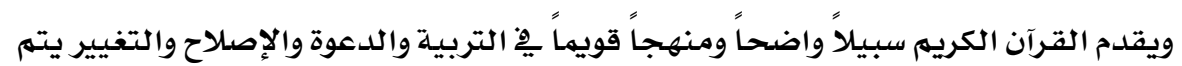

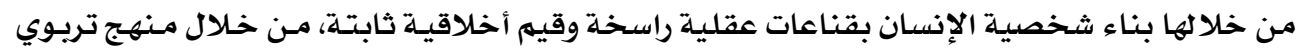

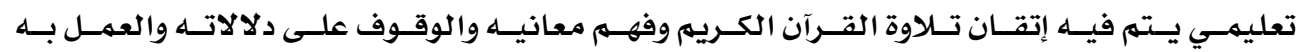
والتخلق بأخلاقه.

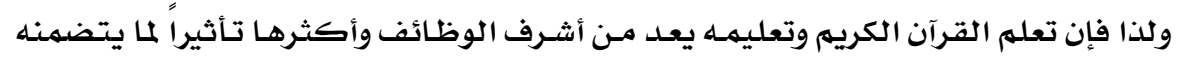

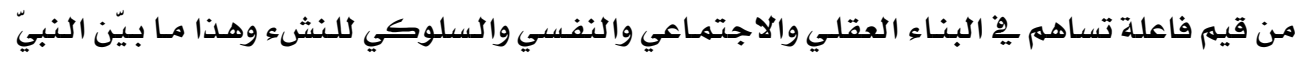

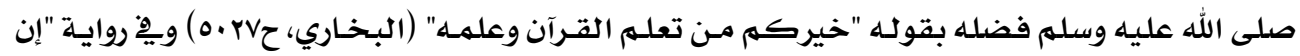

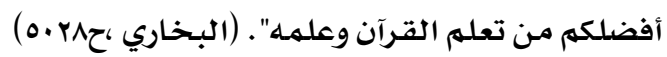

الإطار النظري

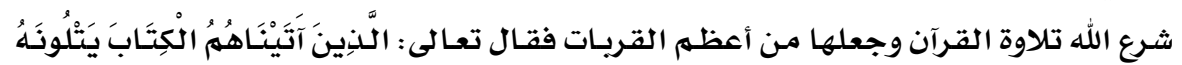

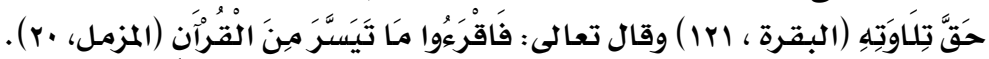

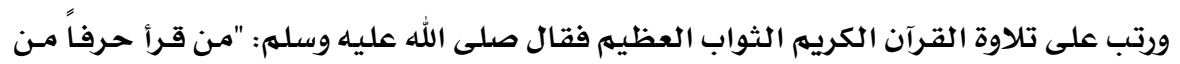

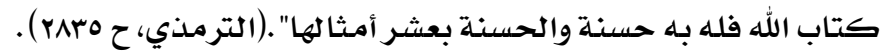

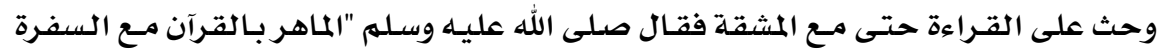

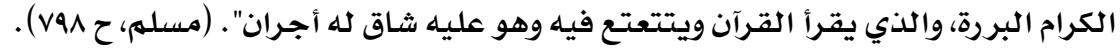

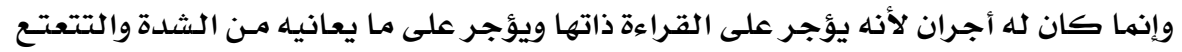

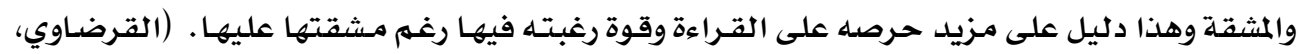

1999، ص707).

* أستاذ مساعد- قسم المناهج وطرق التدريس - كلية التربية - جامعة القصيم 


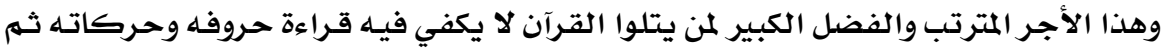

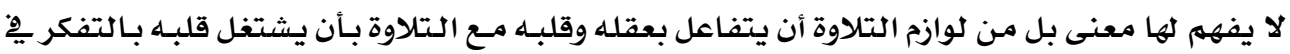
معنى ما يلفظ بـه.

وهذا ما أوضحه السيوطي بتفسيره للفهم والتدبر حيث قال: "أن يتفكر بِّ معنى مـا يلفظ

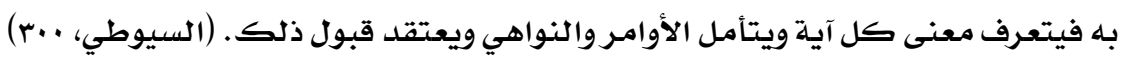

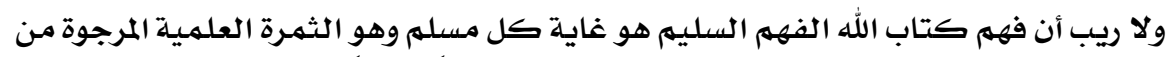

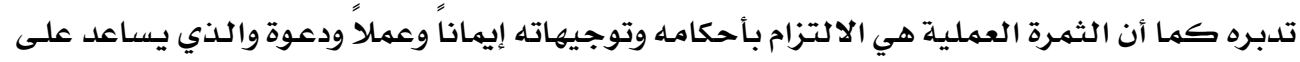

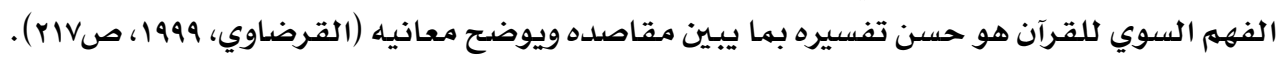
ولذا كان الهدف العام لتدريس تلاوة القرآن الكريم ِِّ مناهج التعليم هو طلب الأجر وزيـادة

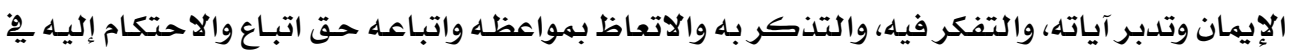

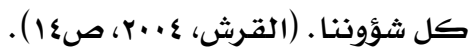

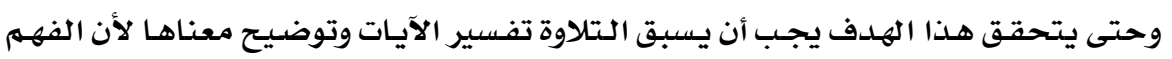

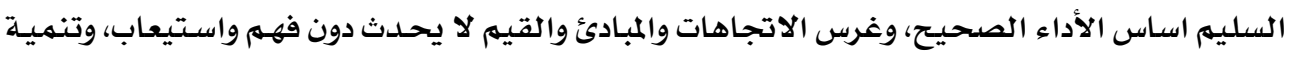

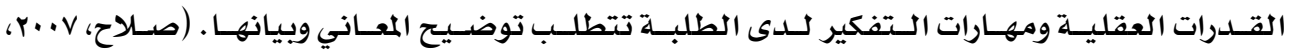

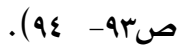

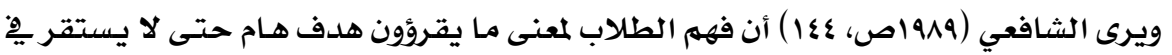

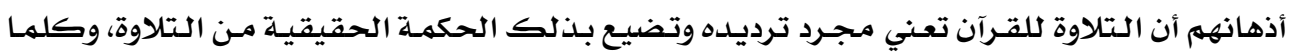

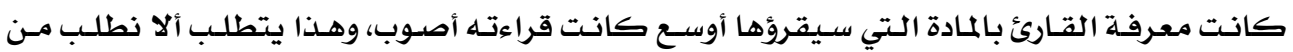

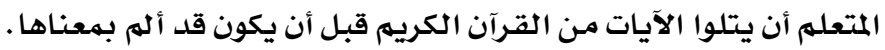

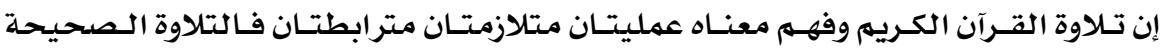

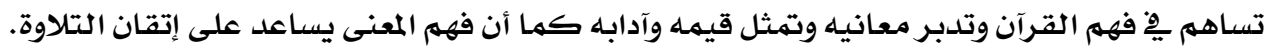

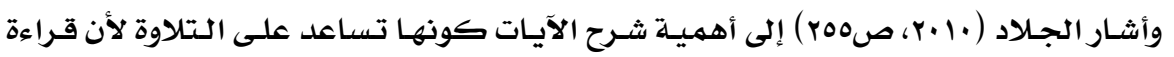

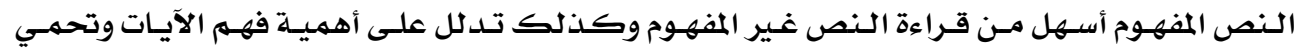

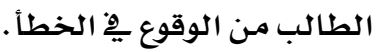
يضاف لذذك أن شرح الآيات يساعد على تحقيق الأهداف الوجدانية وغرس القيم من خلال

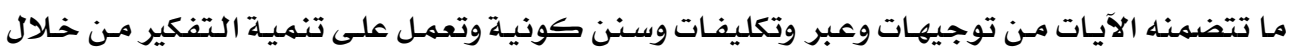

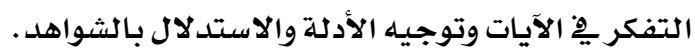
إن هذا التوضيح والشرح لمعنى الآيات ِِّ درس التلاوة ينبغي أن يكون بصورة إجمالية تتضهن

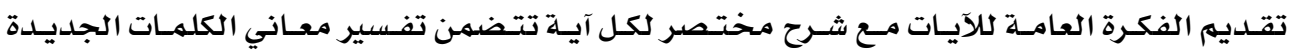

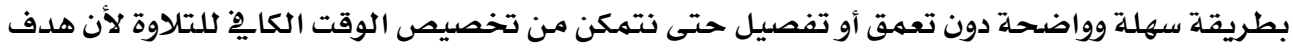

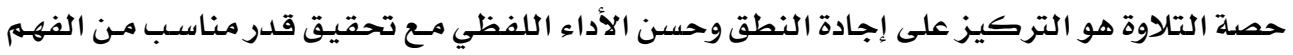




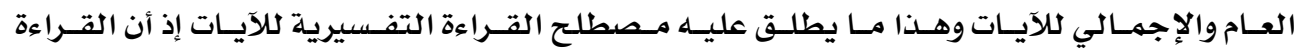

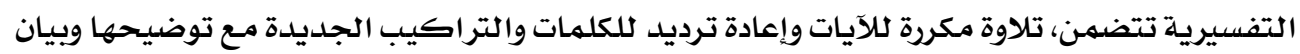
معناها مما يجعل الطالب يألفها.

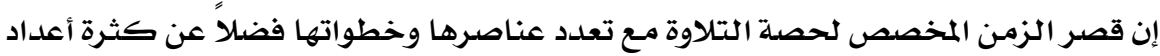

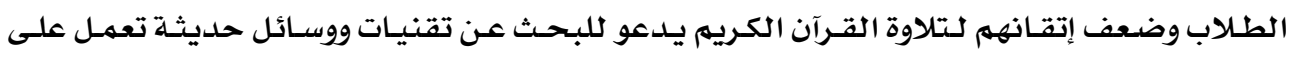

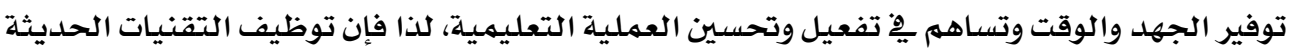

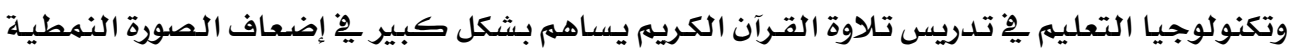

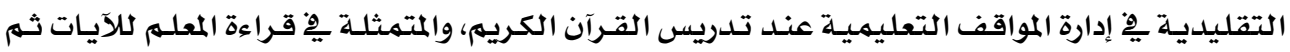

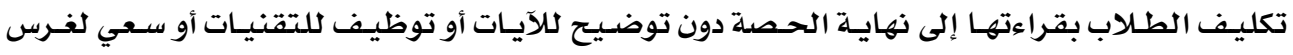

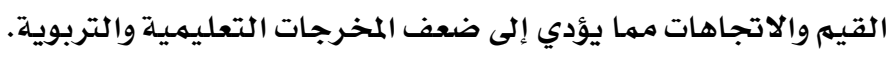

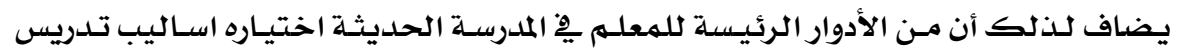

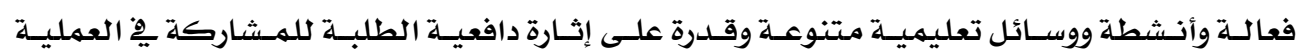

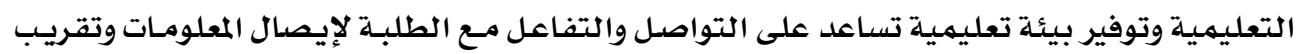

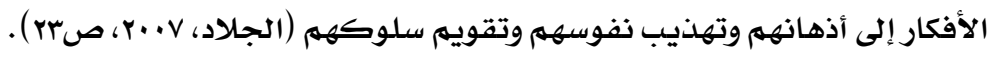

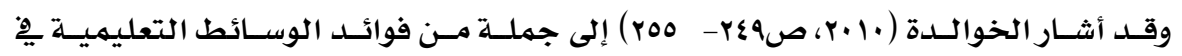

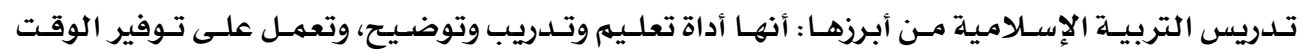

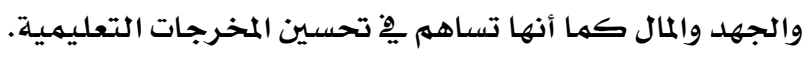

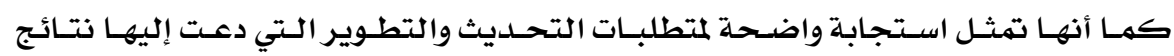

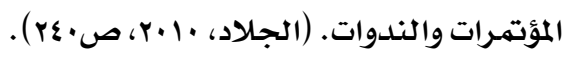

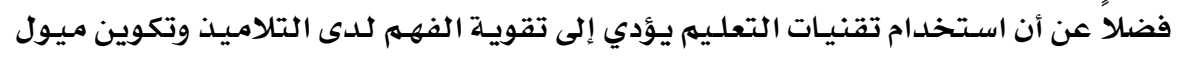

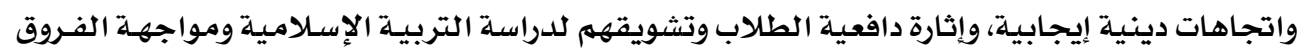

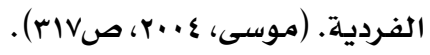

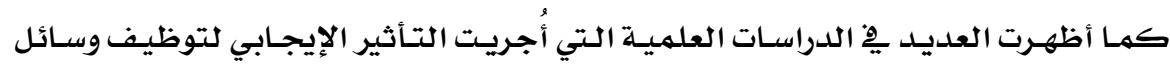

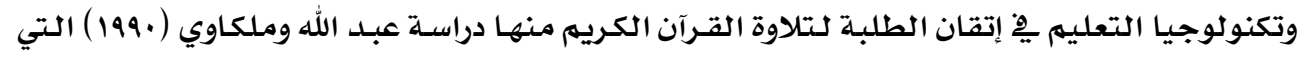

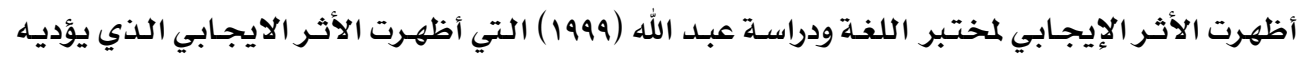

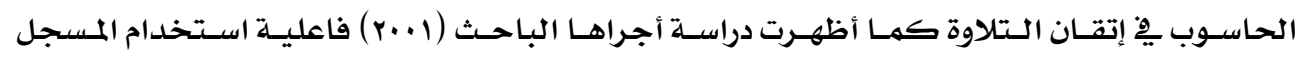

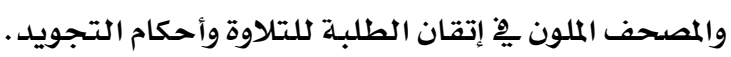

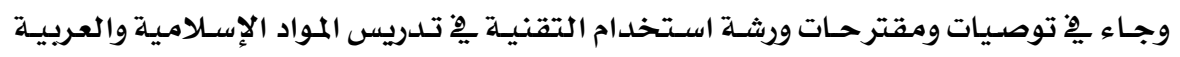

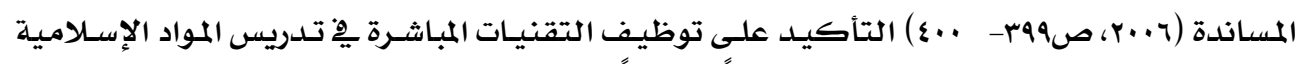

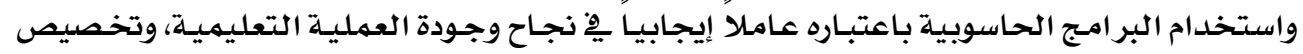
جائزة سنوية حول أفضل مشروع يطور تقنيات التدريس. 


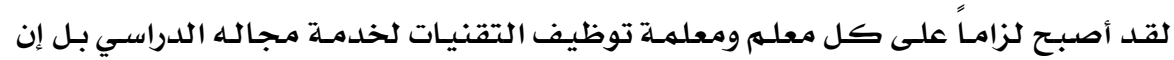

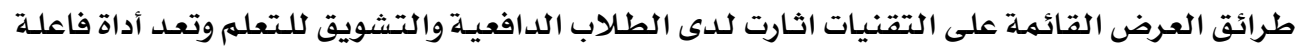
نحو التعلهم الإبداعي الهادف (Davis \& shade 1999, p157).

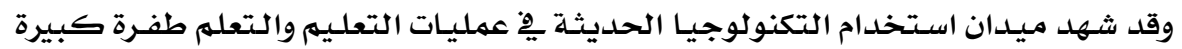

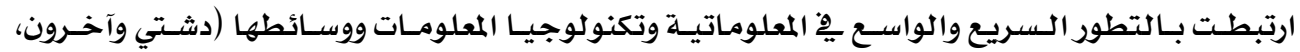

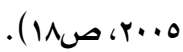

ومن التقنيات التي ظهرت وارتبطت باستخدام الحاسوب تقنية الوسائط المتعددة، وقد حسازت

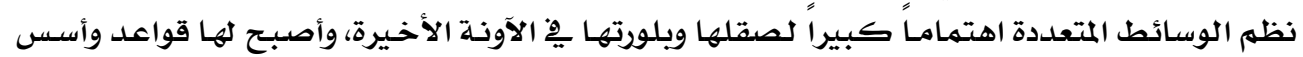

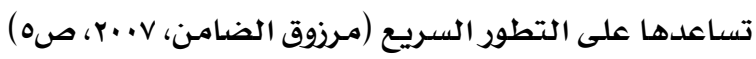
والوسائط المتعددة هي برامج حاسوبية تمزج بين النصوص المكتوبة والمنطوقة والصور المورو الثابتة

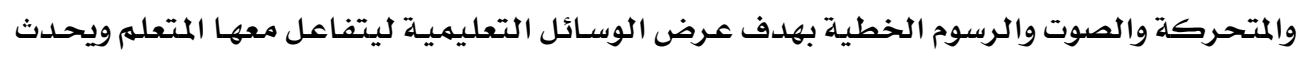

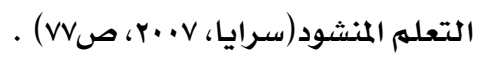

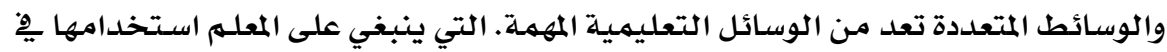

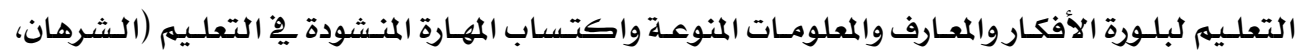
. (1100....

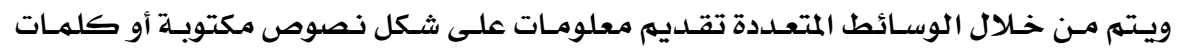

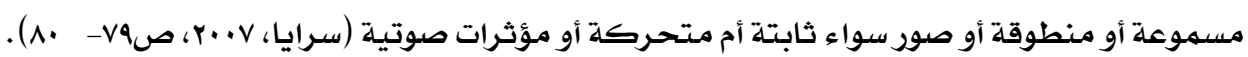

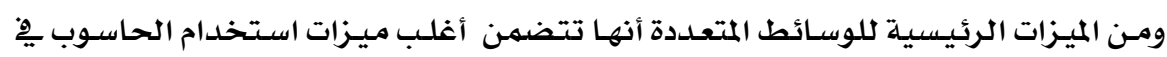

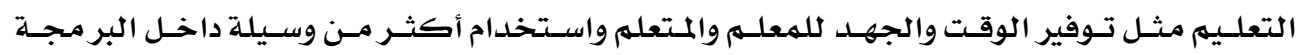

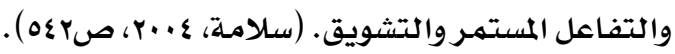

ومن ميزات الوسائط المتعددة كذلك أنها تساعد يِّ تقريب المعلومات للواقع وتعطي فرصسة

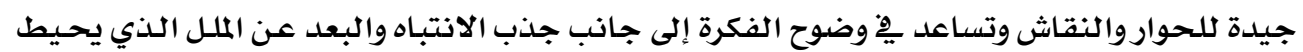

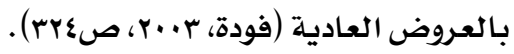

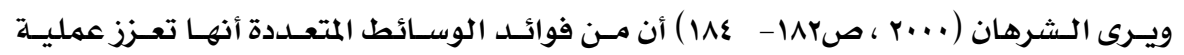

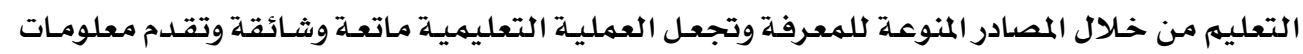

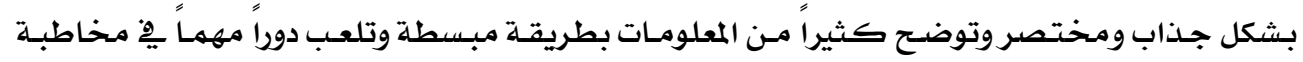

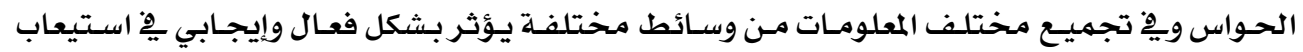
المتعلهم مقارنة بالطرق التقليدية يِّو توضيح المادة العلمية. إن توضيح معاني الآيـات باستخدام الوسـائط المتعـددة، يقوم على ترجمـة وتحويـل الكلهـات والحـروف والألفـاظ إلى معـاني وأصـوات وصـور يسهل حفظهـا وفهمهـا وتخزينهـا ويتحقـق التـاثر بهـا 


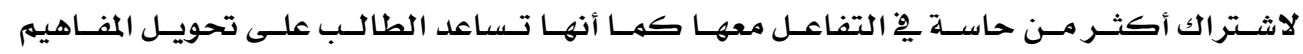
والمصطلحات والمجردات إلى صور حسية تمكن الطالب من الحياة يخ جو النص القرآني.

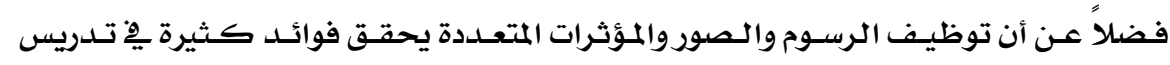

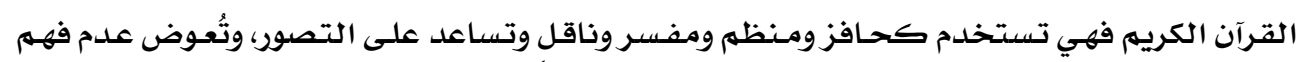

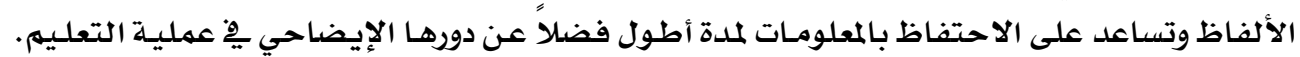

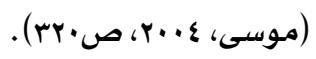

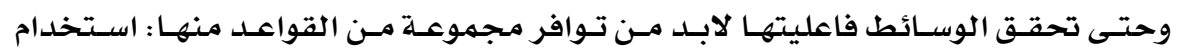

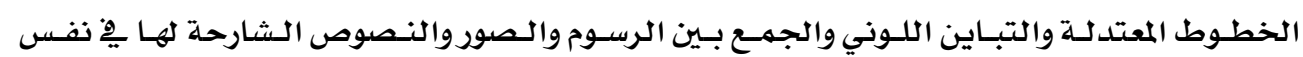
الشاشة مـع إدخال تأثيرات حركيـة على النص. (Tway, 1995, p35)

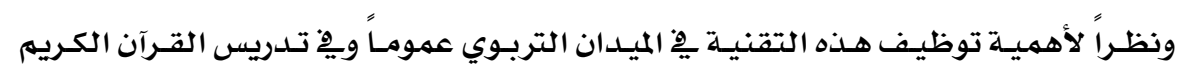
بشكل خاص لما قد يحدثه من آثار إيجابية على العملية التدريسية مها يحقق التعلم الفعّال ويختصر

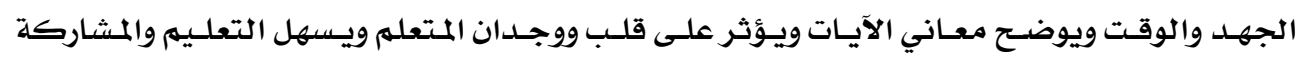

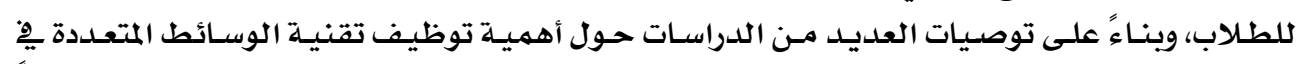

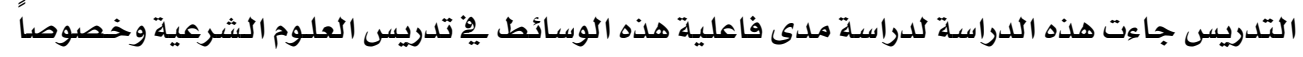
تدريس تلاوة القرآن الكريه.

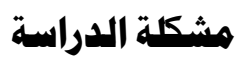

سبق الإشـارة إلى أن أهم أهداف تـدريس القـرآن الكـريهم هـو إتقـان الطلبـة لتـلاوة الآيـات وفهـم

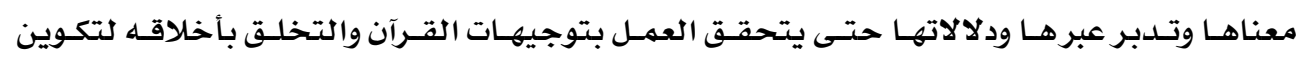

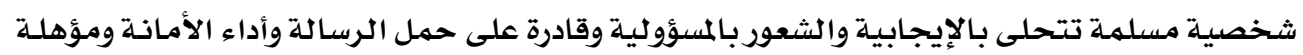
للحياة يخ المستقبـل. ومـن خـلال قيـام البـاحث بـالإثـراف على طلاب التربيـة العمليـة وإطِّلاعـه على واقـع تـريس

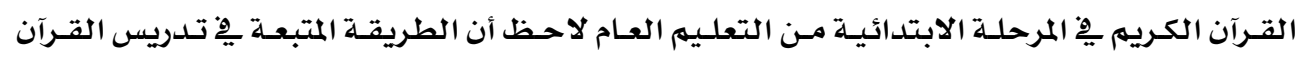

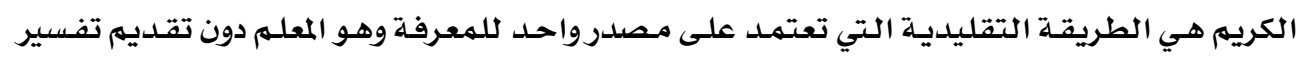

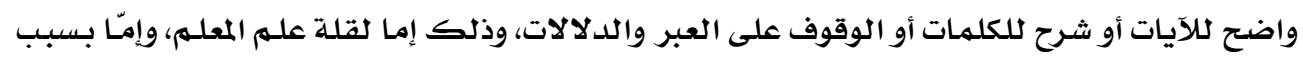

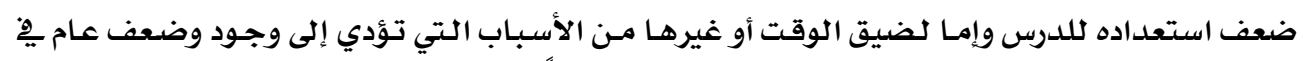

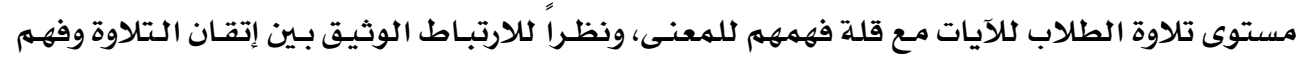

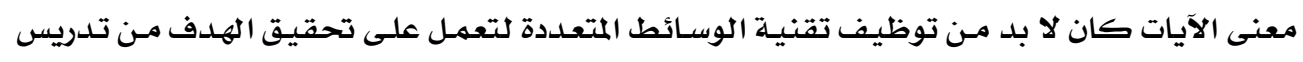

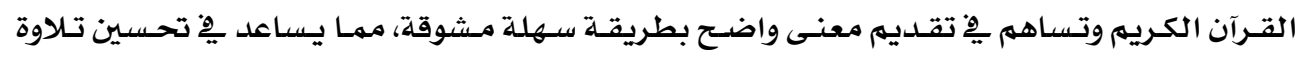
الطلاب للقرآن الكريه، لذا جاءت هذه الدراسـة التي تهدف إلى الكشف عن فاعلية اسـتراتيجية القـراءة

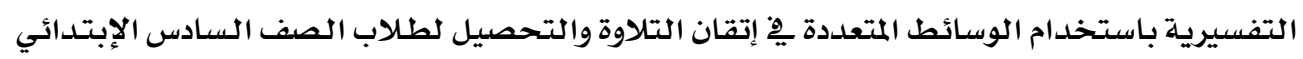
عند تدريسهم وحدة من مقرر القرآن الكريهم. 


$$
\text { ويهكن تحديد مشكلة الدراسلة بالسؤال الآتي: }
$$

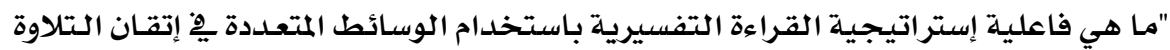

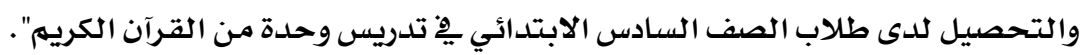

أسئلة الدراسة واستة

تسعى هذه الدراسـة للإجابة عن الأسئلة الرئيسية الآتية:

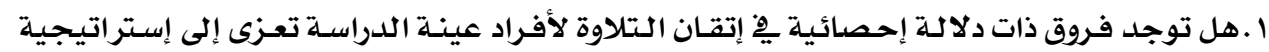
القراءة التفسيرية باستخدام الوسائط المتعددة.

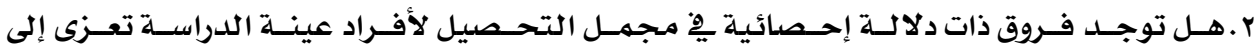

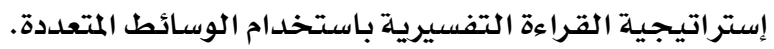

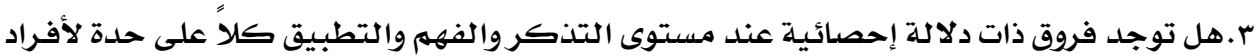

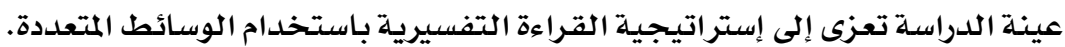

\section{فرضيات الدراسة}

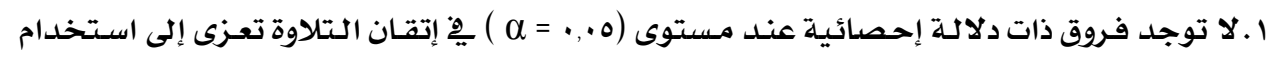

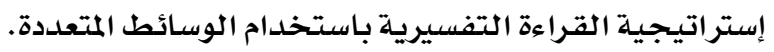

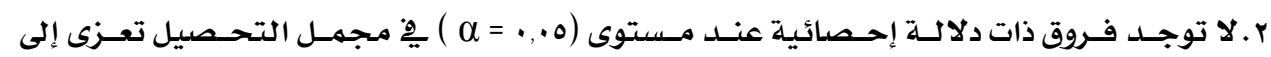

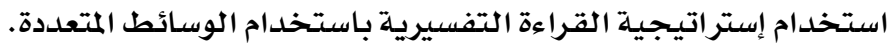

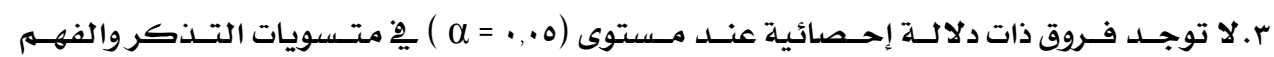

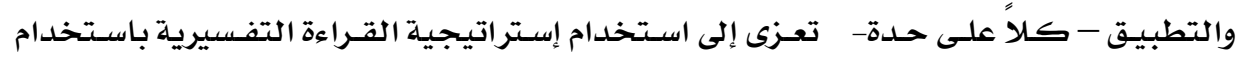
الوسـائط المتعددة.

\section{أهداف الدراسة الدوسئة}

$$
\text { تسعى الدراسـة إلى تحقيق الأهداف الآتية: }
$$

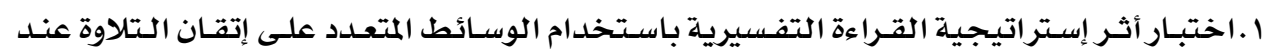

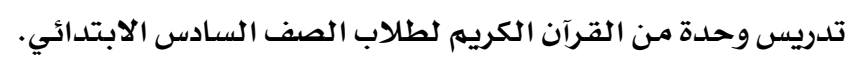

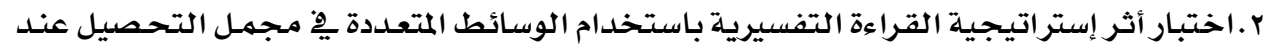

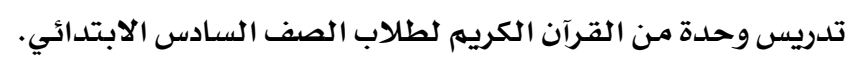

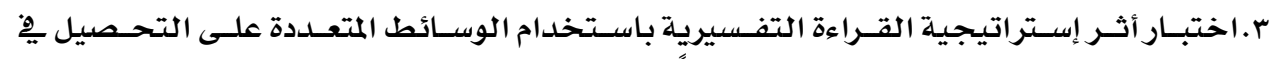

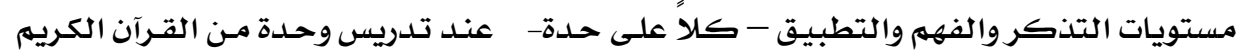

$$
\text { لطلاب الصف السـادس الابتدائي. }
$$




\section{أهمينة الدراسة}

يمكن إبراز أهمية الدراسة من خلال النقاط الآتية: ا.تكتسب الدراسـة أهميتها من مكانة وأهمية تدريس القرآن الكريهم والسعي لتحقيق أهداف تدريسه

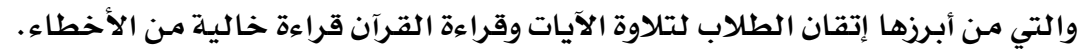

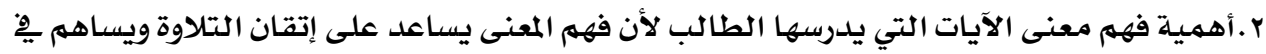

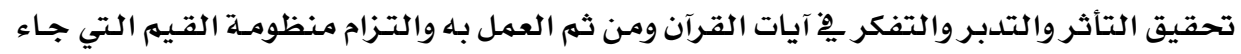
بها القرآن الكريهم.

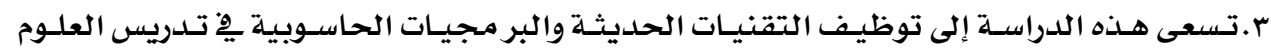

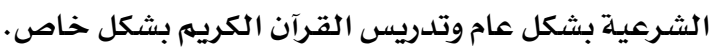

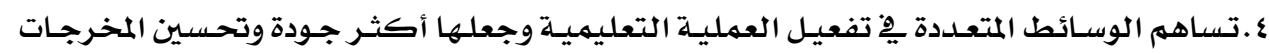

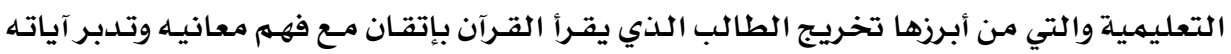
والعهل بأحكامهـ.

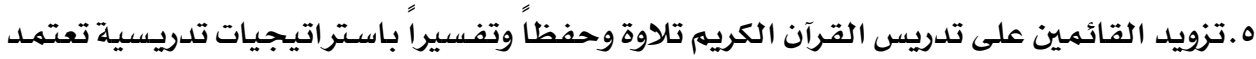

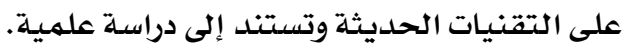

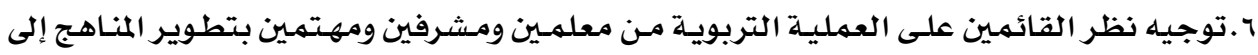

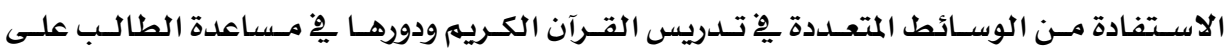
إتقان التتلاوة.

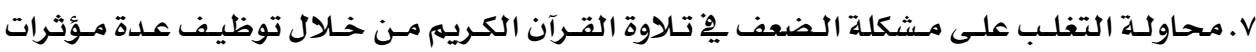

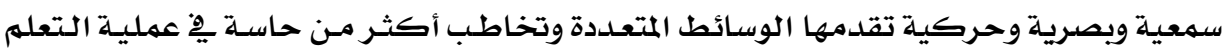

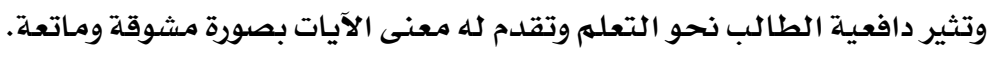

$$
\text { أجريت هذه الدراسة وفق المحلددات الآتية: }
$$

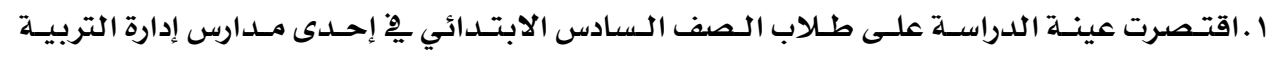

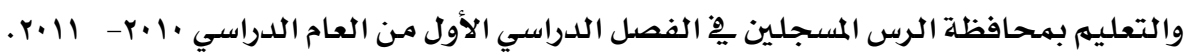

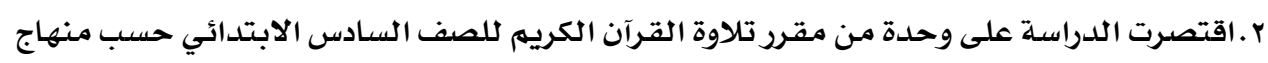

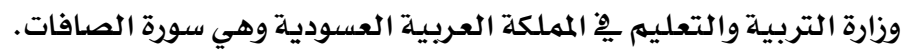

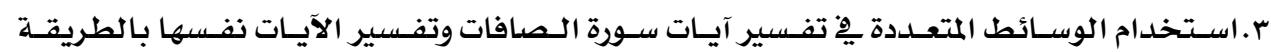
التقليدية. ع . الوسائط المستخدمة يِّة البرنامج هي: الصوت والصور الثابتة والمتحركة والنصوص.

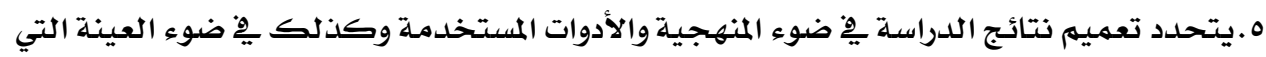
أجريت عليها الدراسـة. 


\section{هصطات الدراسة}

تتضمن الدراسة المصطلحات الآتية:

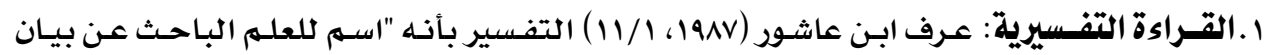

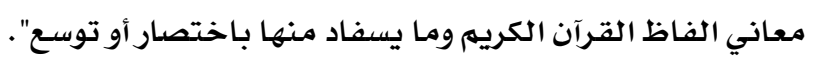

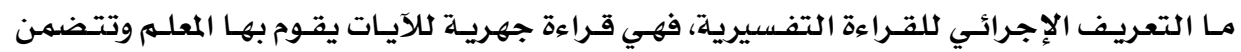

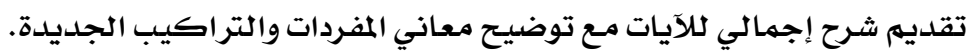

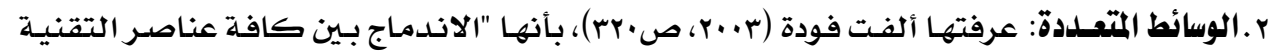

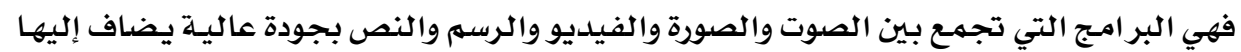

توافر البيئة التفاعلية".

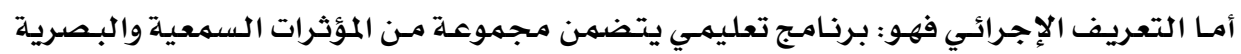

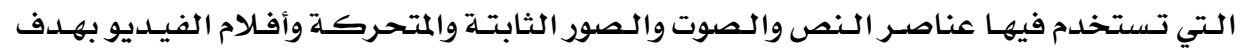

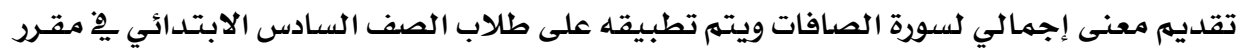
تلاوة القرآن الكريه.

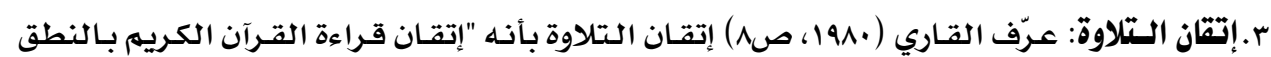

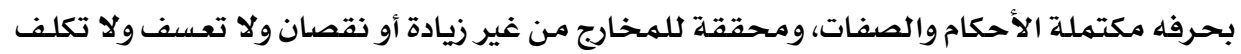

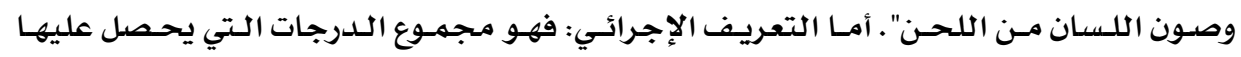

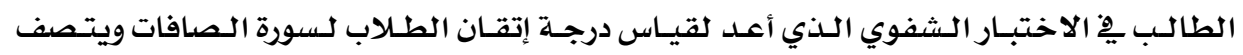
بالصدق والثبات والموضوعية.

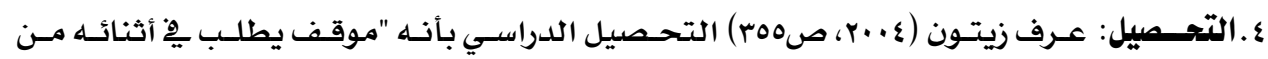

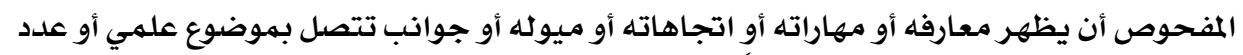

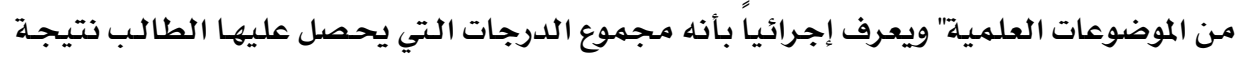

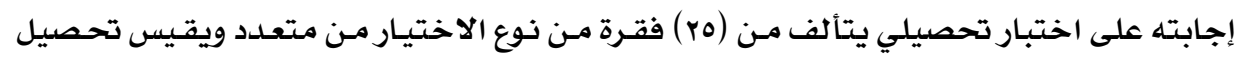

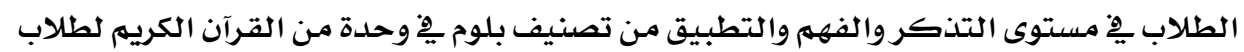

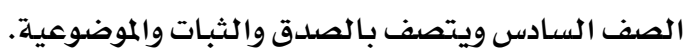

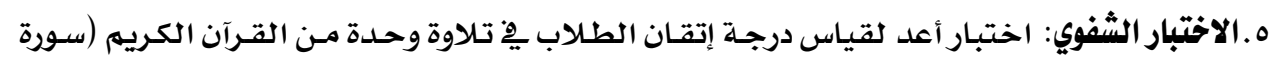

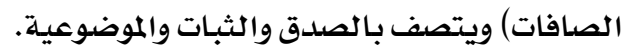

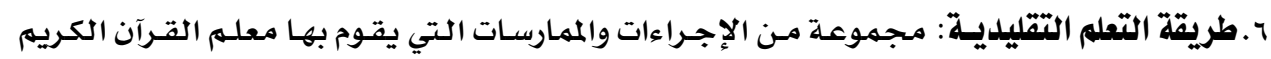

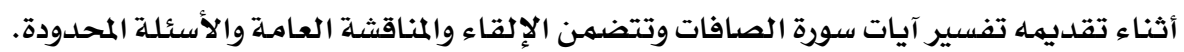

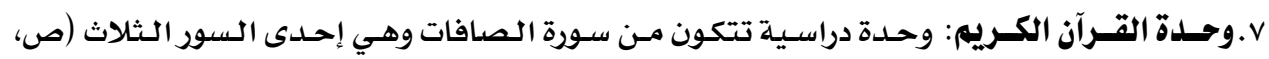

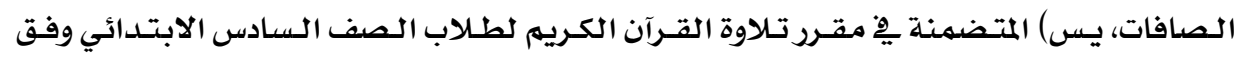

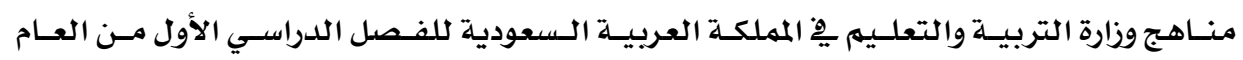

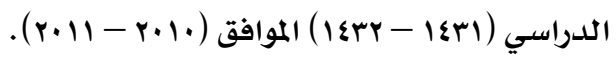


^.الطـلاب: طلاب الصف السـادس الإبتـدائي المسجلين يِّ المدارس الحكوميـة التابعـة لإدارة التربيسة

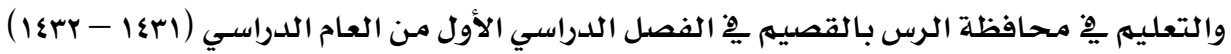

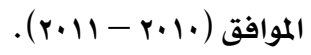

\section{الدراسات السابقة}

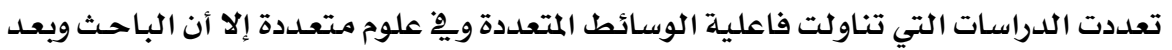

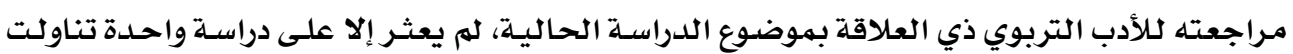

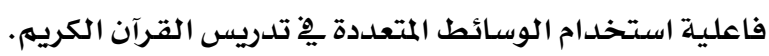

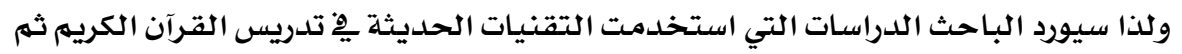

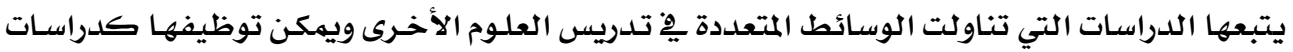
سابقة وكذلك بعض الدراسات الأجنبية التي تناولت الوسائط المتعددة.

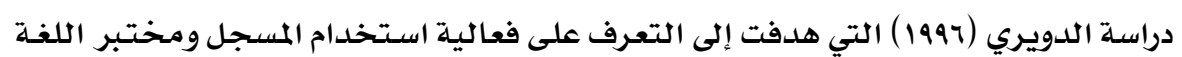

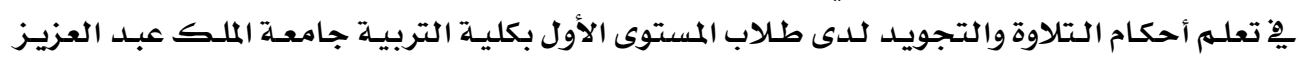

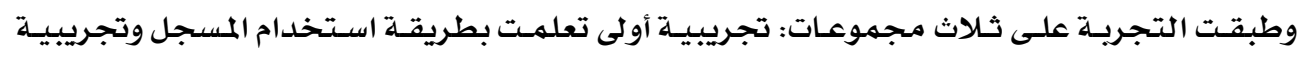

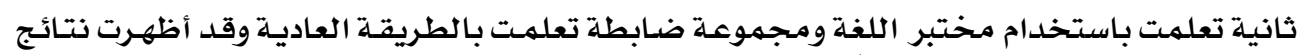

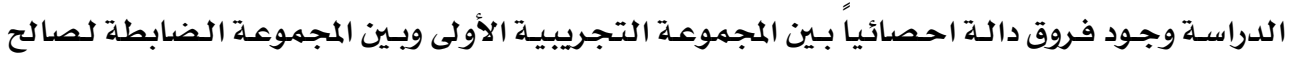

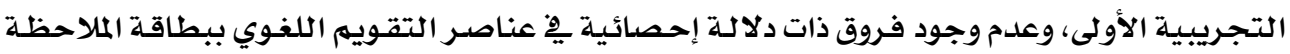

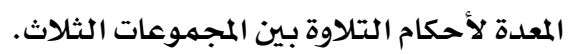

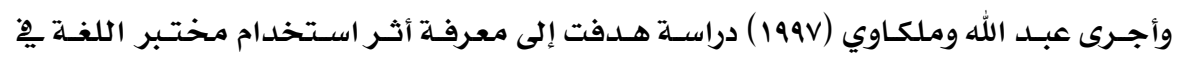

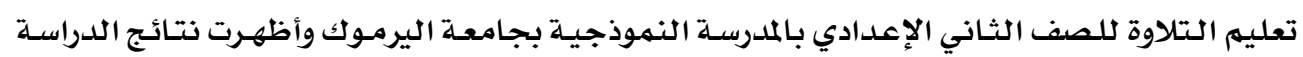

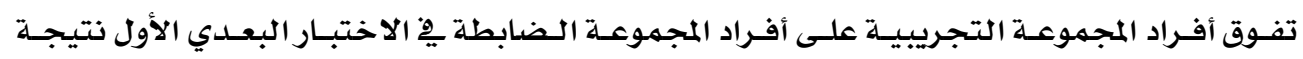

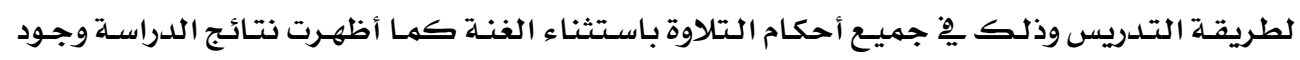

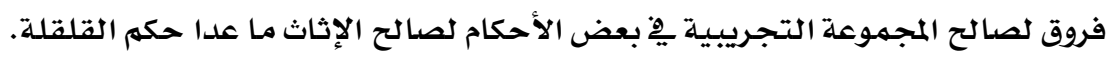

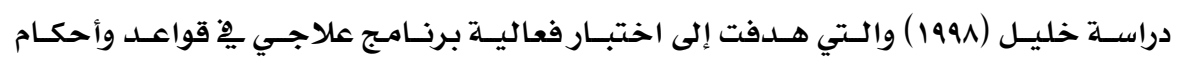

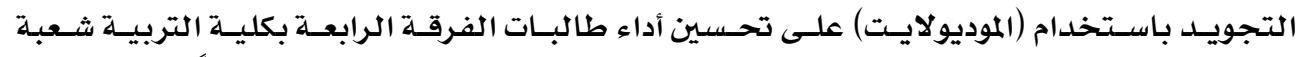

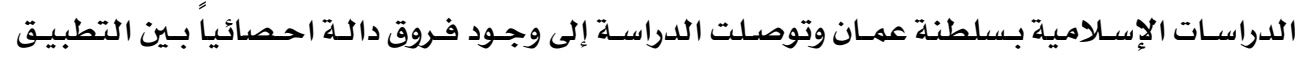

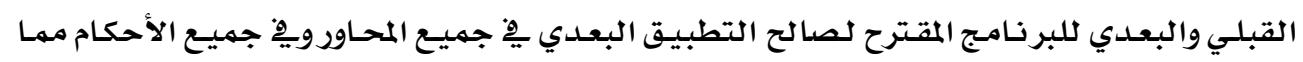

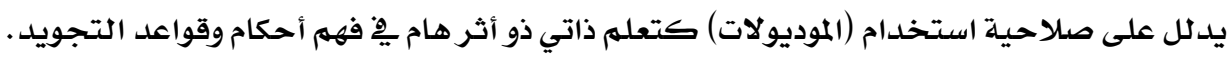

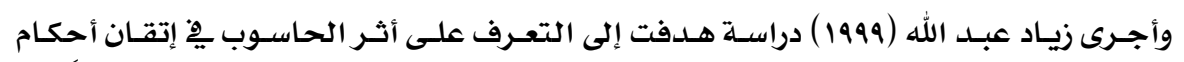

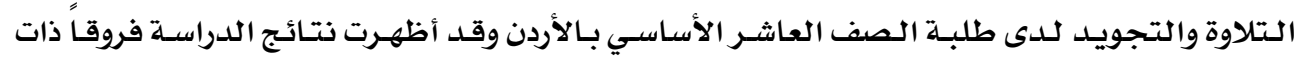

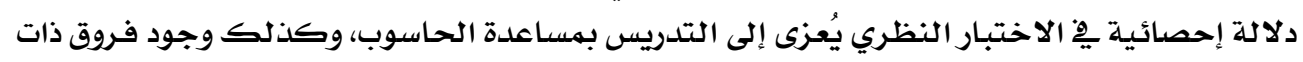

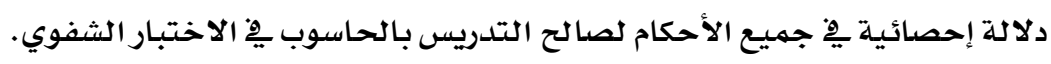




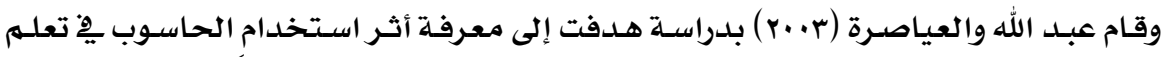

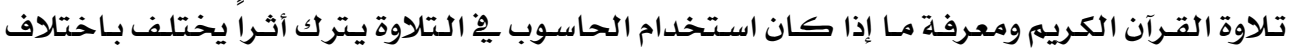

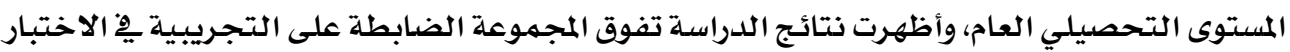

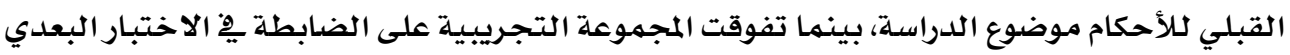

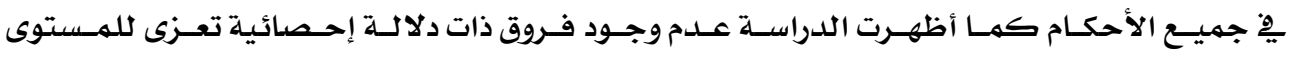
التحصيلي العام للطلاب.

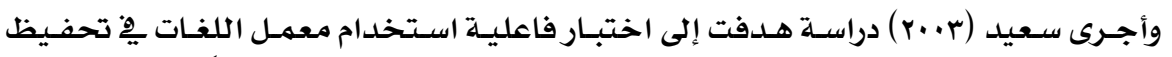

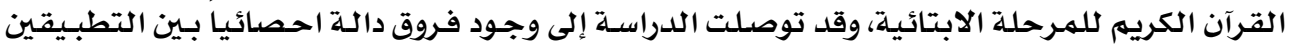

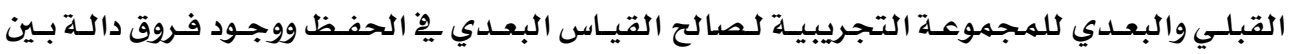

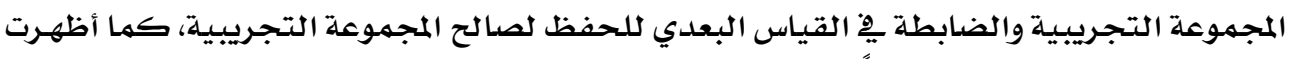

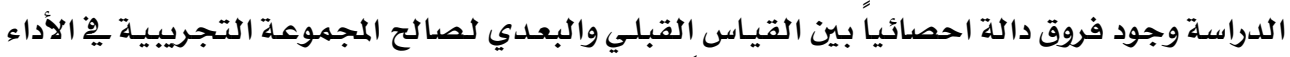

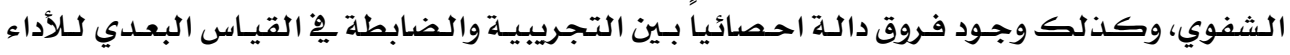
الثفوي لصالح المجموعة التجريبية.

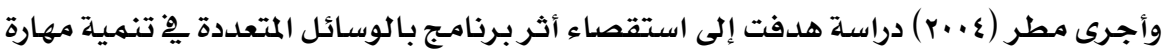

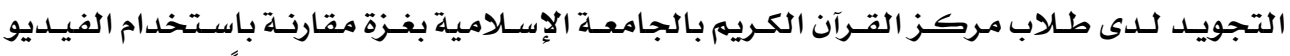

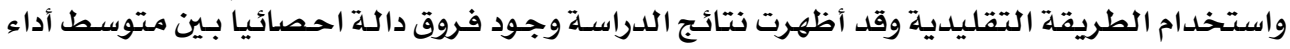

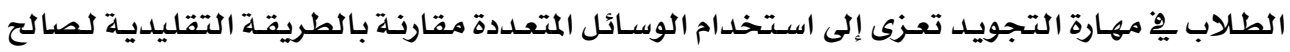

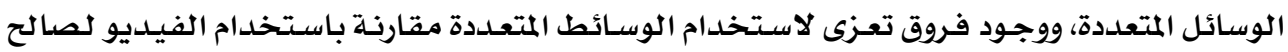

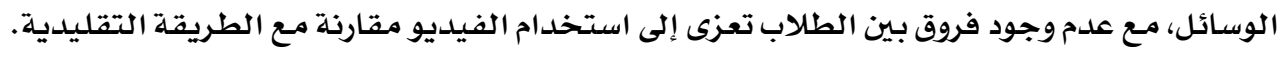

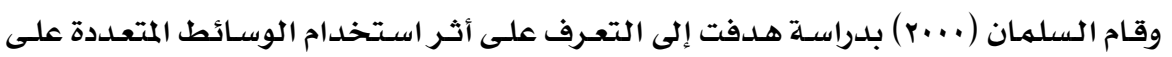

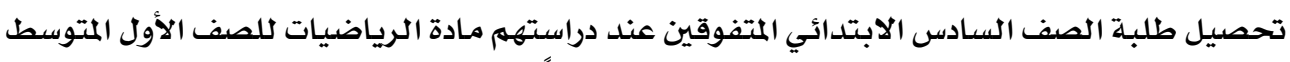

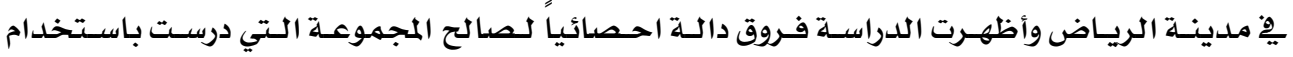

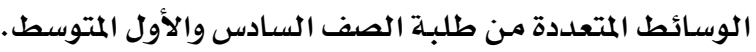

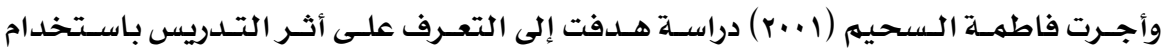

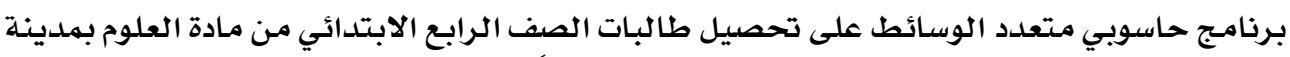

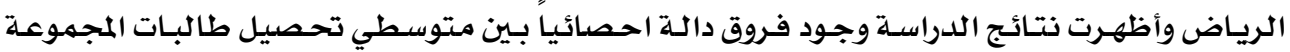

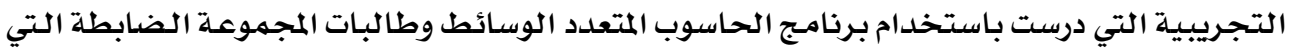

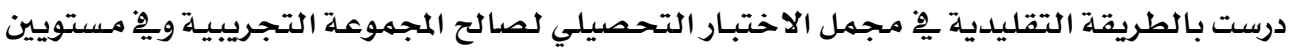

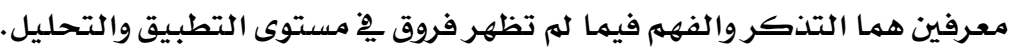

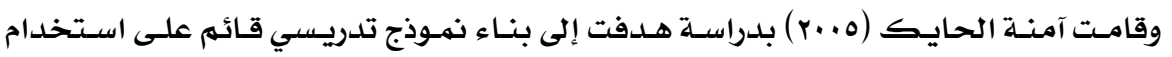

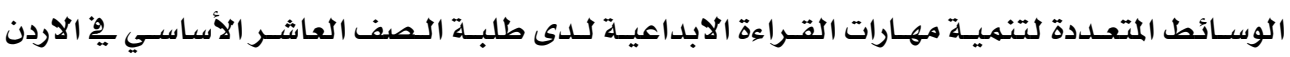

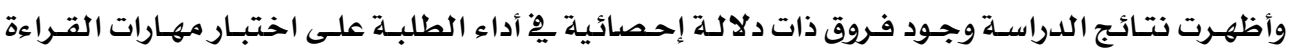


الابداعيـة، وأظهـرت عدم وجـود فـروق ذات دلالـة إحصـائية يِّ أداء الطلبـة على اختبــار مهـارات القـراءة

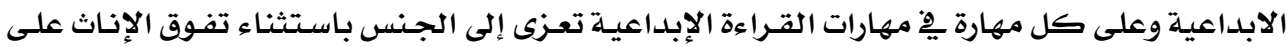
الذكور يِّ مهارة الطلاقة.

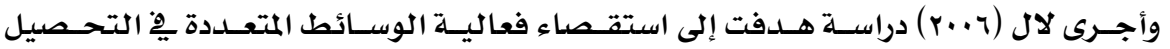

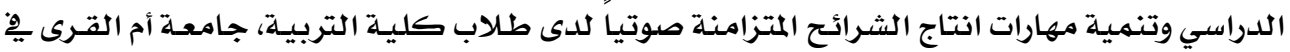

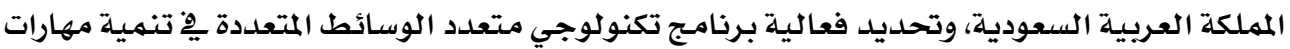
تصميم انتاج الشرائع المتزامنة صوتئة المودياً.

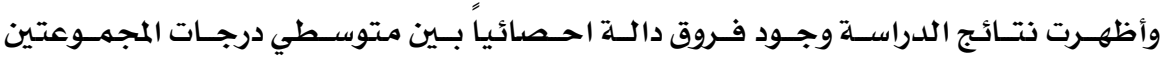
التجريبية والضابطة لصالح المجموعة التجريبية التي درست باستخدام الوسائط المتعددة.

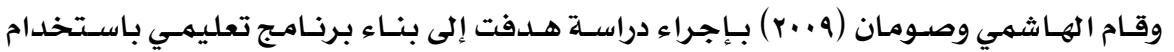

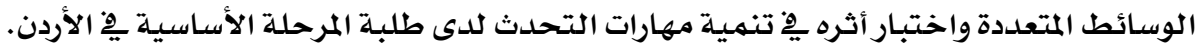
وقد أظهرت نتائج الدراسة وجود فروق دالة احصائيا لصالح المجموعة التي درست البرنامـج

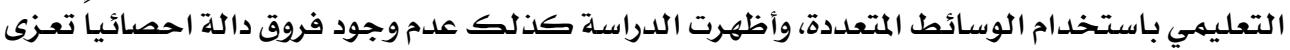

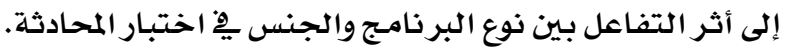

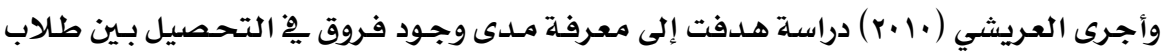

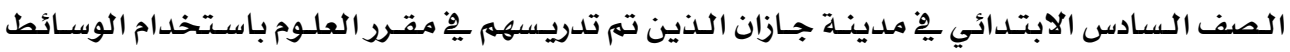

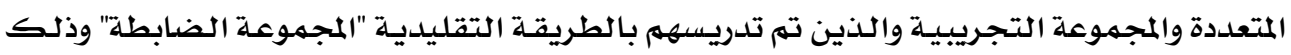

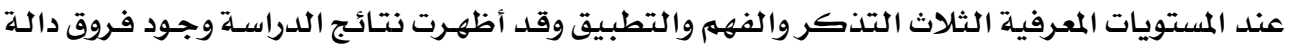

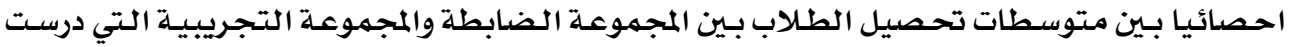

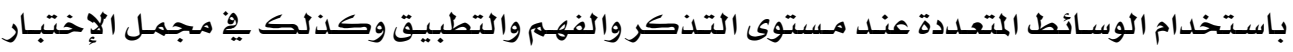
التحصيلي ولصالح المجموعة التجريبية.

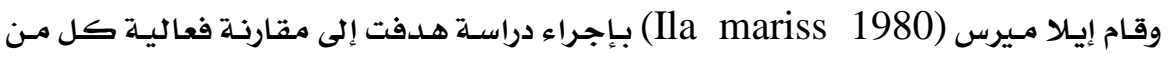

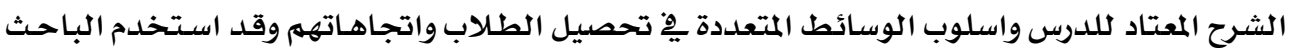

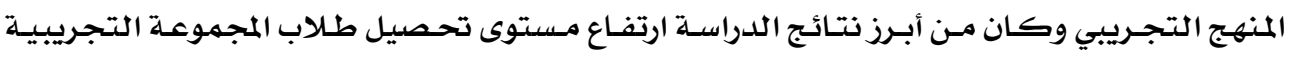

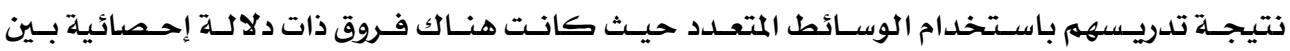

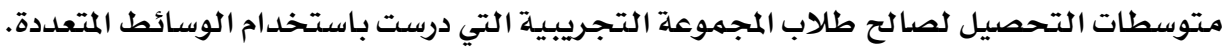

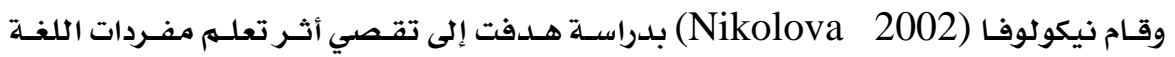

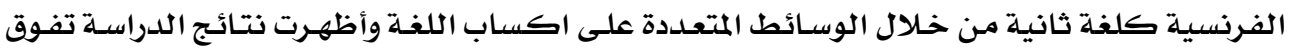

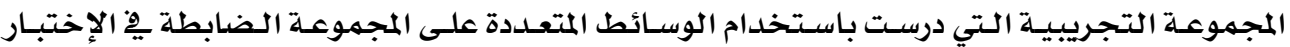

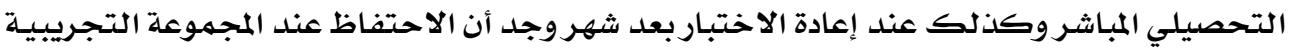


وأجـرى فابري (Fabry 1998) دراسـة هـدفت إلى استقصـاء فعاليـة برنـامـج تفـاعلي متعـدد

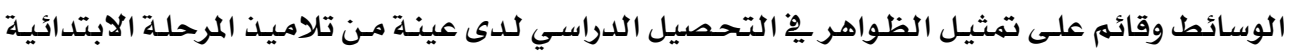

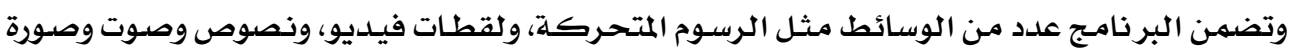

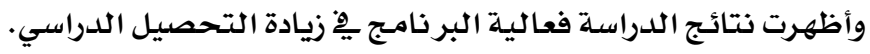

\section{تمقيب على الدراسات السابقة}

من خلال القراءة المتأنية للدراسات السابقة يتضـح فعاليـة تقنيـة الوسـائط المتعددة ِِِ زيـادة

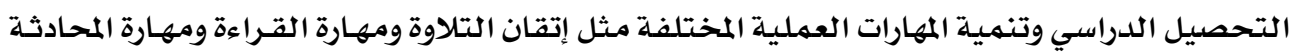
ومهارة تصميم الشرائح وغيرها يِّي المهارات.

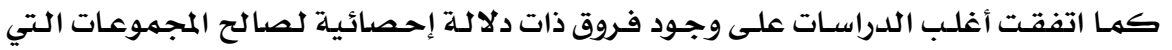

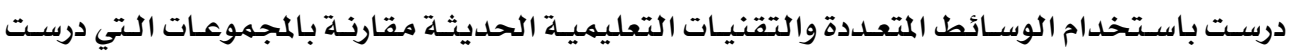
بالطرق التقليدية أو بوسائل تعليمية بسيطة الفيطة وأظهرت الدراسـات تعسدد الآثار الإيجابيـة لاستخدام التقنيـات الحديثة والوسـائط المتعسددة

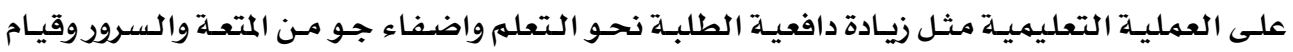
الطالب بلدور نشط ِِ العملية التعليمية.

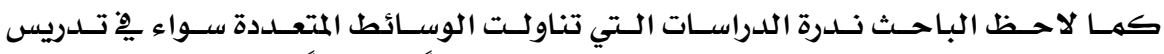

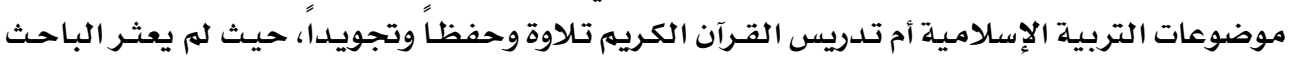

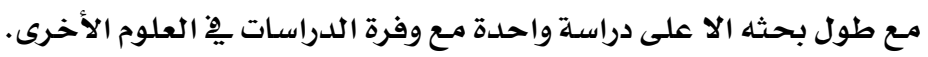

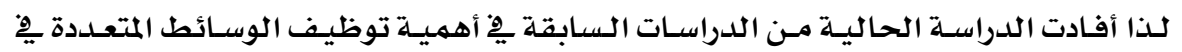

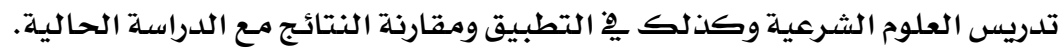

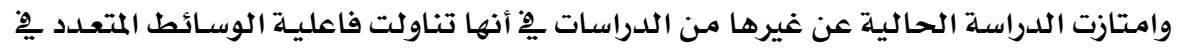

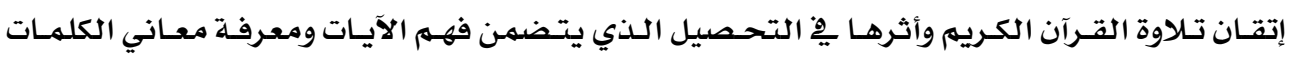
والمفردات لدى طلاب الصف السـادس الابتدائي.

إجراءات الدراسة وأدواتها منهج الدراسة

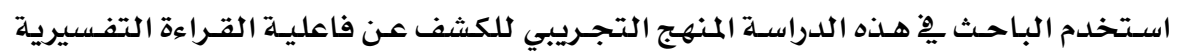

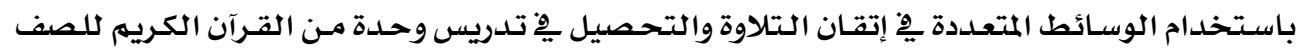

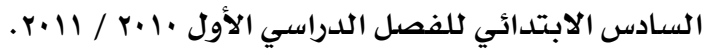
مجتمع اللدراسة الابتاتي

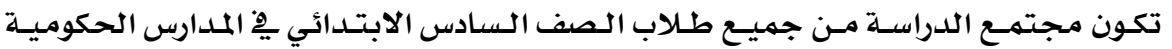

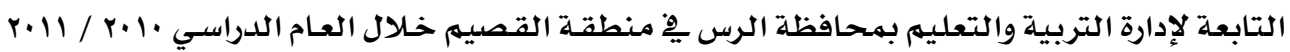

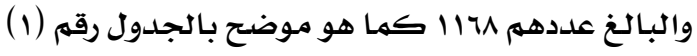




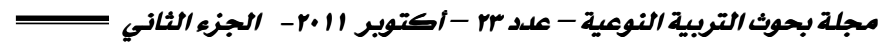

جدول رقم (1) توزيـع مجتمهـع البحث على المدارس والشعب

\begin{tabular}{|c|c|c|}
\hline عدد الطلاب & علد الشعب & عدد الملدرس \\
\hline 1171 & 19 & $v_{1}$ \\
\hline
\end{tabular}

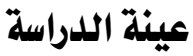

تكونت عينـة الدراسة من (وس) طالبـاً مسن طلاب الصف السـادس الابتدائي فِ مدرسسة موسىى بن نصير الابتدائية بادرس حيث تضهم المدرسة شعبتين للصف السـادس الابتدائي تم توزيعهما بطريقـة عشوائية إلى مجموعة تجريبية ومجموعة ضابطة كما هو موضـع يِّا الجدول رقم (r) . جدول رقم (r) (r)

\begin{tabular}{|c|c|}
\hline عدد الطلاب & المجموعة \\
\hline$r \cdot$ & التجريبية \\
\hline 19 & الضابطة \\
\hline$r q$ & المجموع \\
\hline
\end{tabular}

حيـث درسـت المجمهوعـة التجريبيـة القـراءة التفسيريـة باستتخدام الوسـائط المتعسددة يف حـين درست المجموعة الضـابطة القراءة التفسيرية بالطريقة العادية لوحدة القرآن الكريهم مـن مقـرر القـرآن الكريهم على طلاب الصف السـادس الابتدائي.

وتم اختيـار مدرسسة موسـى بـن نصير لتطبيق الدراسـة بالطريقـة القصلديـة لانها ثمثل واقع

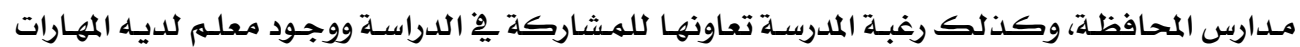

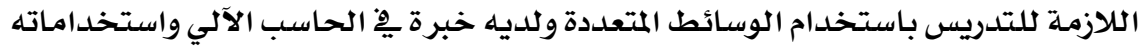

أدوات الدراسة الدراتة أولاً: برنامج القراءة التفسيرية باستخدام الوسائط التملدة تم تصهيهم البرنامـج التعليهي وفق الخطوات الآتيـة:

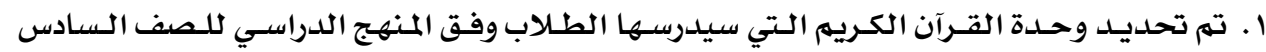
الابتـدائي وحسب خطـة الإشـراف التربـوي يخ توزيـع المفـردات، وهـي سـورة الصـافات، وقـام البـاحث بتحزئَة السورة إلى سبعة مقاطع، يتضهن كل مقطع فكرة محلددة رئيسية وخصص لكل مقطع حصدة دراسيـة واحدة.

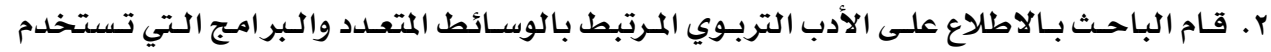

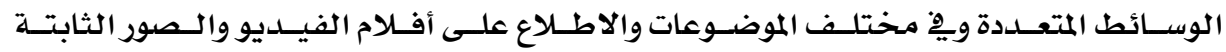

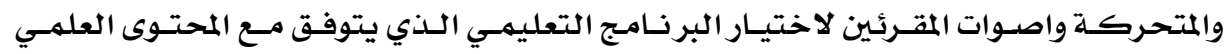
ويناسب المرحلة العمـرية لعينـة الدراسـة.

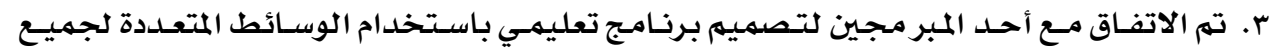
مقاطع سورة الصافات بحيث يتضهن كل مقطع المؤثرات الصوتية والحركيـة والصور والأفلام

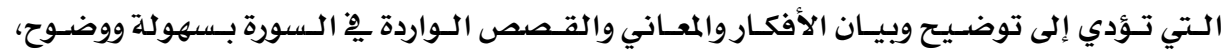


والمناسبـة للمحتــوى التعليهـي مـع مـراعـاة الـضوابط الشـرعية عنــ اختيـار الصوروالآيـات وقـام

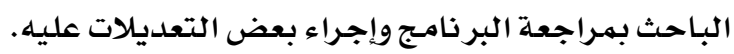

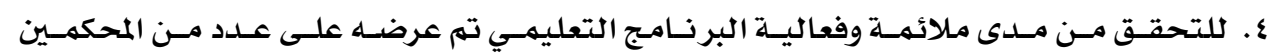

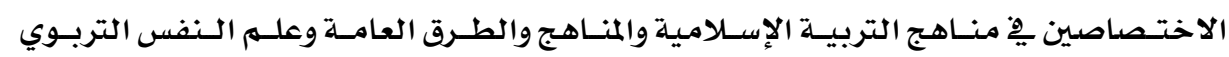

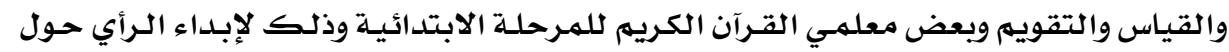

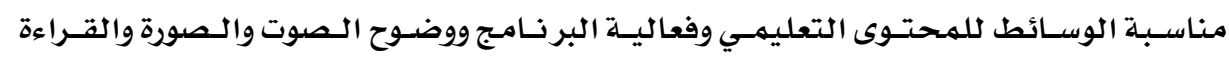

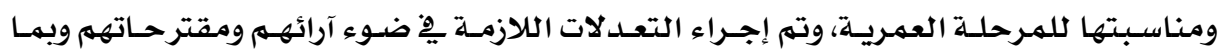

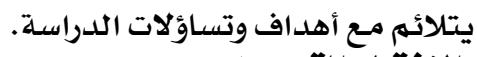
ثاذياً: الاختبار التحصييلي

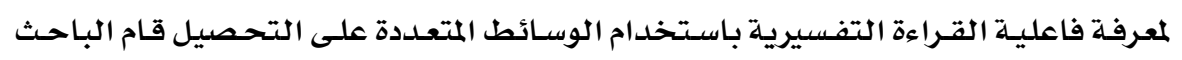

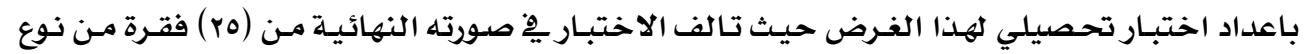

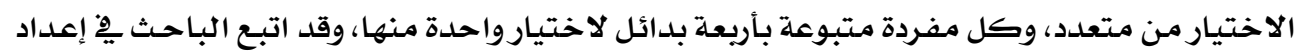
الاختبار الخطوات الآتية: الاختيار من متعلد

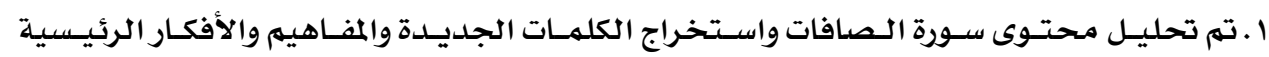
والمعلومات الأساسية الواردة فيها.

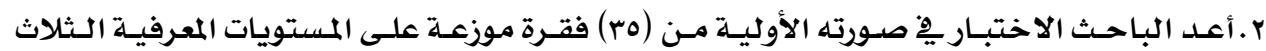

$$
\text { التذكر، الفهم، التطبيق. }
$$

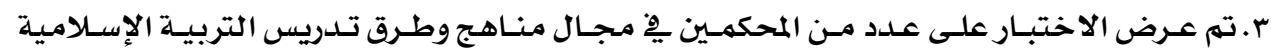

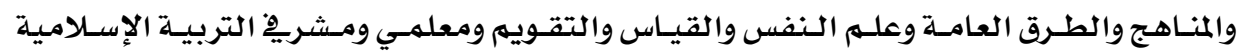

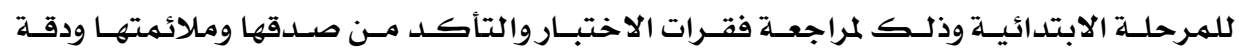

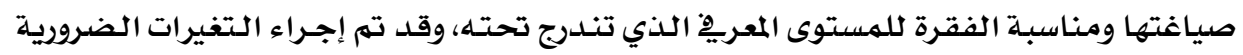

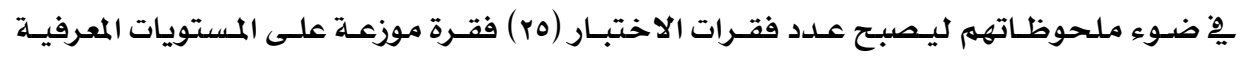

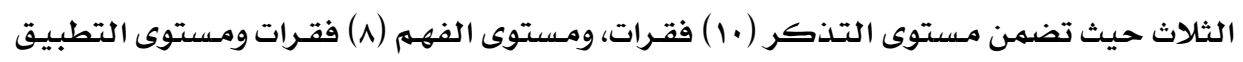

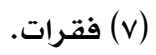

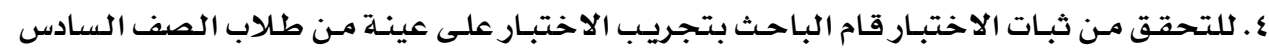

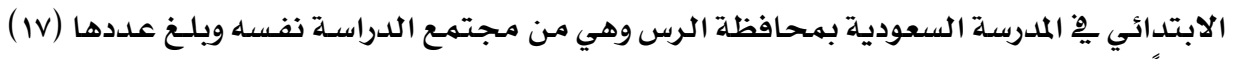

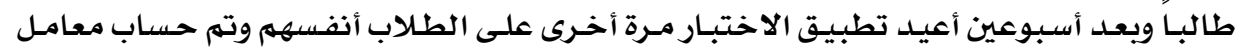

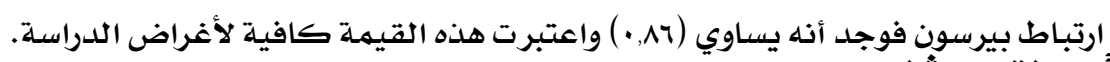

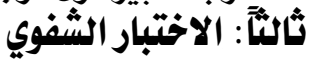

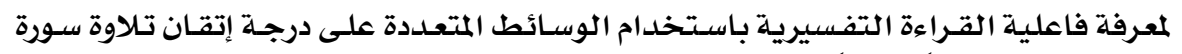

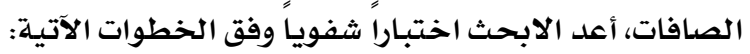




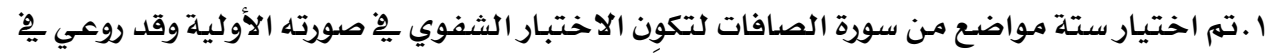

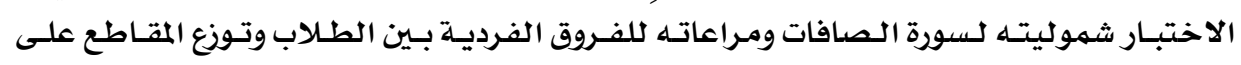

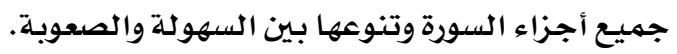

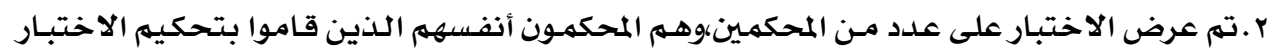

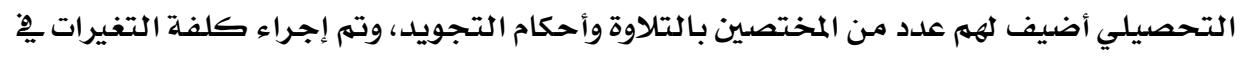

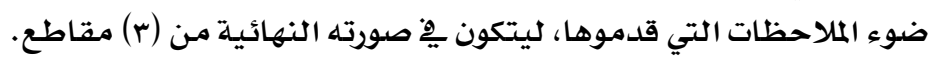

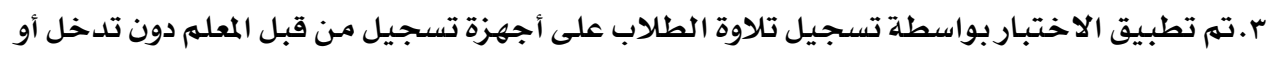

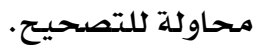
ع. لتقويم درجـة إتقـان الطلاب لـتلاوة الآيـات تم اختيـار اثنين مـن المصححـين مهـن يتقنـون التـلاوة

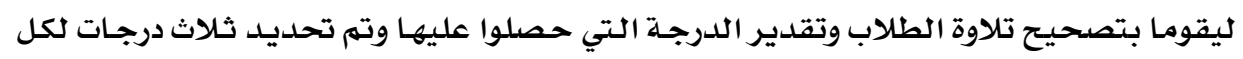

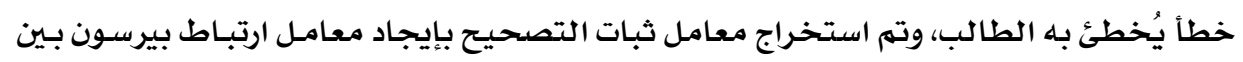

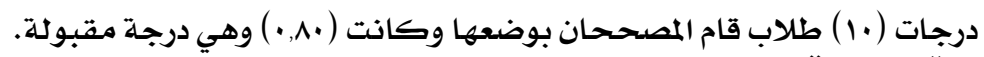

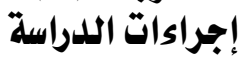

$$
\begin{aligned}
& \text { اتبعت الدراسة الحالية الإجراءات الآتية: } \\
& \text { I. إعداد برنامجج القراءة التفسيرية باستخدام الوسائط المتعددة. }
\end{aligned}
$$

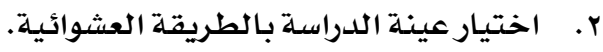

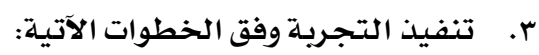

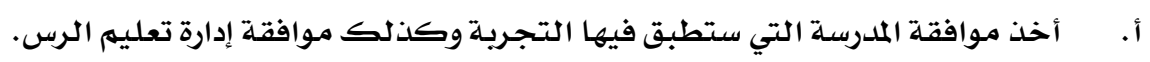

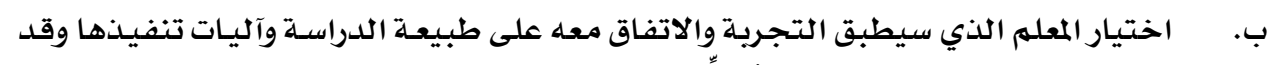

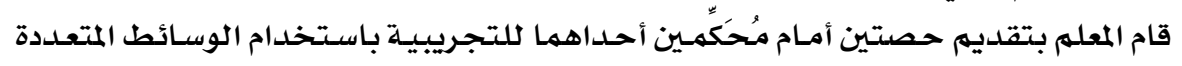

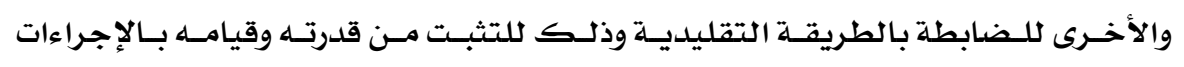

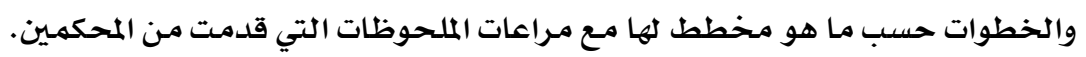

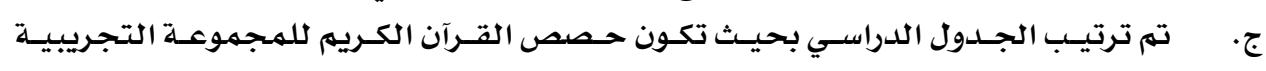

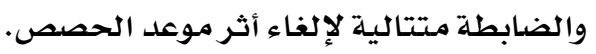

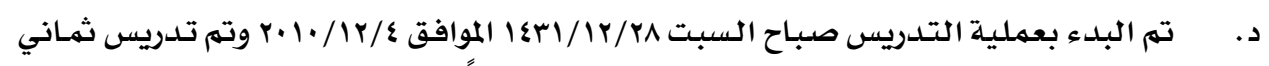
حصص موزعة على أريعة أسابيع بواقع حصتين أسبوعياً.

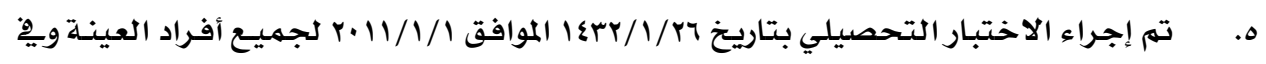
الوقت نفسه لضمان عدم تسرب الأسئلة.

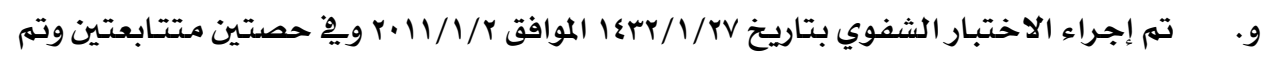

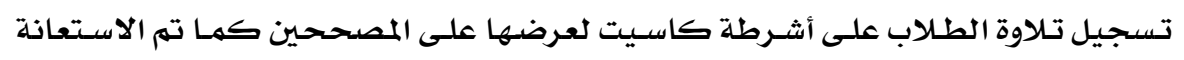

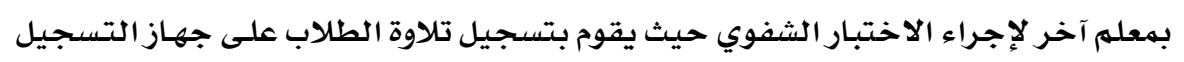
دون تدخل يِّ تلاوة الطلاب. ز. تم جمع البيانات والنتائج وإجراء التحليلات الإحصائية المناسبة وإعلان النتائج وتفسيرها. 
تتكون هذه الدراسـة من متتغيرات مستقلة وتابعة حسب الآتي: ا . المتغيرات المستقلة: طريقة التدريس ولها مستويان هما : أ. إستر اتيجية القراءة التفسيريـة باستخدام الوسائط المتعددة.

$$
\begin{aligned}
& \text { ب. الطريقة التقليدية. } \\
& \text { ץ. المتتغيرات التتابعة وهي: } \\
& \text { أ. إتقان التتلاوة. }
\end{aligned}
$$

ب. التحصيل وفق المستويات الثلاثة الأولى من تصنيف يلوم وهي التذكر والفهم والتطبيق.

\section{نتائج الدراسة}

يتناول هذا الفصل عرضاً لنتائج الدراسـة، التي هدفت إلى معرفة فاعلية إستراتيجية القراءة

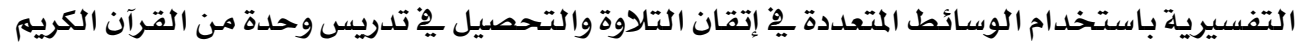
لدى طلاب الصف السادس الابتدائي، وذلك من خلال الإجابة عن أسئلة الدراسة الآتية:

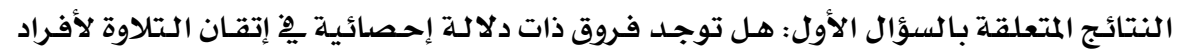

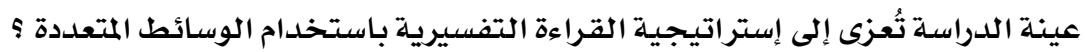

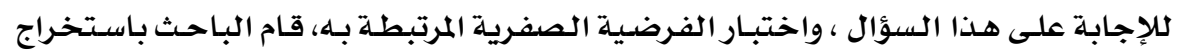

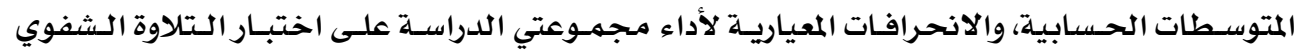
البعدي، والجدول الآتي يوضح ذلكية، والكرات

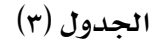

\begin{tabular}{|c|c|c|c|c|c|c|}
\hline \multicolumn{2}{|c|}{ الاختبار البعدي } & \multicolumn{2}{|c|}{ التحصيل القبلي } & \multirow{2}{*}{ النهاية العظمى } & \multirow{2}{*}{ العدد } & \multirow{2}{*}{ المجموعة } \\
\hline الانحراف المعياري & المتوسط الحسابي & الانحراف المعياري & المتوسط الحسابي & & & \\
\hline Ir, qr & Ar, 10 & $\wedge, \vee \uparrow$ & $A r, r \cdot$ & \multirow{2}{*}{1.0} & r. & التجريبية \\
\hline 19,99 & $90, Y_{1}$ & $\Lambda, r q$ & $\wedge r, \wedge q$ & & 19 & الضابطة \\
\hline
\end{tabular}

المتوسطات الحسـابية والانحرافات المعياريـة لأداء مجمهوعتي الدراسـة على اختبـار التلاوة الشفوي البعدي وعلاماتهم القبلية

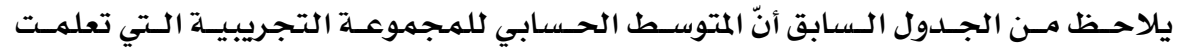
باستخدام إستراتيجية القـراءة التفسيريـة باسـتخدام الوسـائط المتعـددة كـان الأعلى إذ بلـغ (07,rی)،

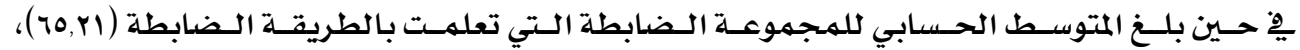

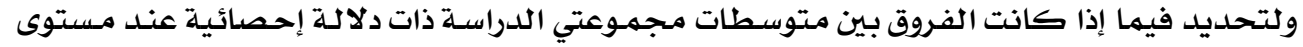
دلادة (ه.., = = م) قام الباحث بتطبيق تحليل التباين المشترك الأحسادي (ANCOVA)، وجـاءت نتائج تحليل التبـاين المشترك على النحو الذي يوضحه الجدول التالي: 
مجلة بحوث التربية النوعية - عدد rr - أكتوبر ll ا.r- الجزء الثانسي

$$
\text { (ع) الجدول) }
$$

نتائج تحليل التبـاين المصاحب (ANCOVA) للفروق بين متوسطات تحصيل طلاب مجموعتي الدراسـة على اختبار التلاوة الشفوي البعدي

\begin{tabular}{|c|c|c|c|c|c|}
\hline مستوى الدلالة & قيهة (ف) المحسوبة & متوسط المربعات & درجات الحرية & مجموع المربعات & مصلدر التباين \\
\hline •,ArY & $\bullet, \bullet \leqslant 9$ & $1 \varepsilon, 1 r r$ & 1 & $1 \xi, \mid r r$ & التحصيل القبلي \\
\hline \multirow[t]{3}{*}{$\cdot, \cdot \bullet r$} & $\|$ & rrA9,rrs & 1 & rrA9, rrs & الإستراتيجية \\
\hline & & rAA, rII & ry & 1.rYO,OA & الخطأ \\
\hline & & & ra & Irv.r, Ir & المجموع \\
\hline
\end{tabular}

يظهر من الجـدول السـابق أن قيمهة ( ف ) بالنسبـة لإستراتيجية التدريس بلغت (ساع,11) ،

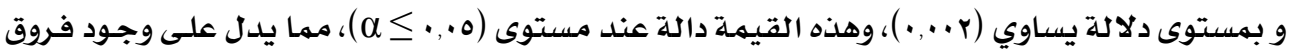
ذات دلالة إحصائية بـين متتوسطات أداء مجهموعتي الدراسلة على اختبـار التتلاوة الشفوي البعـدي، وهـذا

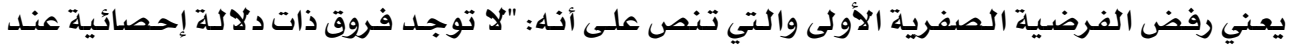

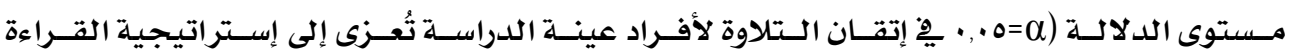

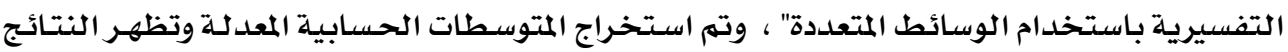
مِِ الجدول الآتي:

(0) الجددول)

المتوسطات الحسابية المعدلة والأخطاء المعياريـة لتحصيل طلاب مجموعتي الدراسـة على اختبـار التلاوة الشفوي البعدي باختلاف إستراتيجية التدريس

\begin{tabular}{|c|c|c|c|}
\hline الخطأ المعياري & المتوسط الحسابي & العلدد & المجموعة \\
\hline$r, \Lambda$. & Ar, Ir & r. & التجريبية \\
\hline$r, q$. & $70, Y \varepsilon$ & 19 & الضابطة \\
\hline
\end{tabular}

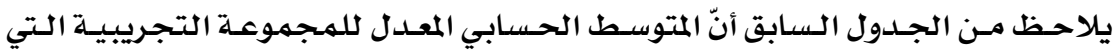

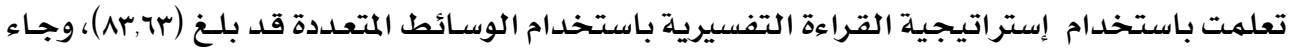

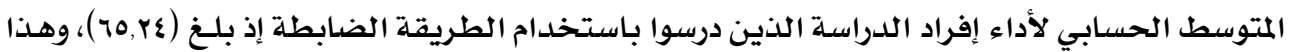
يشير إلى أن الفـرق كـان لـصالح المجموعـة التجريبيـة الـتي تعلهـت بـاسـتخدام إسـتراتيـيـة القـراءة التفسيريلة باستخدام الوسـائط المتعددة ، بمعنى وجود أثر لإسـتراتيجيـة القـراءة التفسيرية باستتخدام

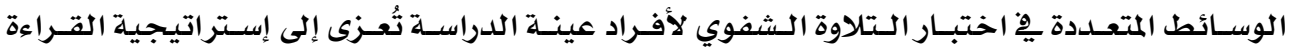
التفسيرية باستخدام الوسائط المتعددة.

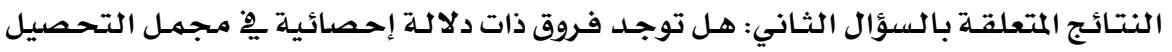

لأفراد عينـة الدراسـة تُعزى إلى إستراتيـجية القراءة التفسيريـة بـاستخدام الوسـائط المتعددة ؟ ؟ 
لإججابــة علـى هــذا الـسؤال واختبــار الفرضـيـة الـصفريـة المرتبطـة بـه، قـام البـاحسث

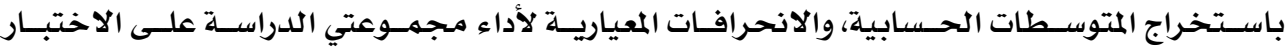
التحصيلي الإجمالي البعدي، والجدول الآتي يوضدح ذلك:

(7) الجددول)

المتوسطات الحسـابية والانحرافات المعياريـة لأداء مجموعتي الدراسـة على الاختبـار التحصيلي الإجمالي البعدي وعلاماتهم القبلية

\begin{tabular}{|c|c|c|c|c|c|c|}
\hline \multicolumn{2}{|c|}{ الاختبار البعلدي } & \multicolumn{2}{|c|}{ التحصيل القبلي } & \multirow{2}{*}{ النهاية العظىى } & \multirow{2}{*}{ 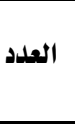 } & \multirow{2}{*}{ المجموعة } \\
\hline الانحراف المعياري & المتوسط الحسابي & الانحراف المعياري & المتوسط الحسابي & & & \\
\hline $9,99 r$ & Vr, \&. & $\Lambda, \vee \uparrow$ & $A r, r$. & \multirow{2}{*}{$1 .}$. & r. & التجريبية \\
\hline Ir,Arv & 91.71 & $\Lambda, r q$ & $\wedge Y, \wedge q$ & & 19 & الضابطة \\
\hline
\end{tabular}

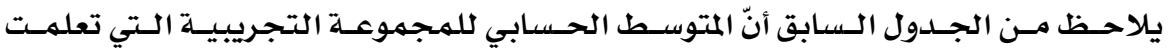

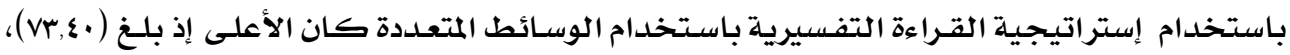

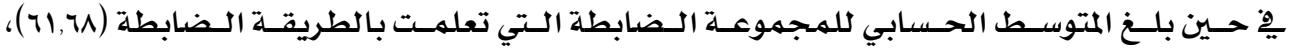

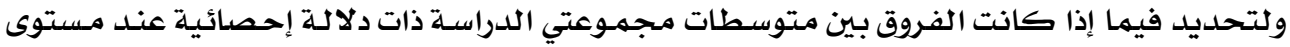
دلادلة (ه •, ، = م) قام البـاحث بتطبيق تحليل التبـاين المشترك الأحسادي (ANCOVA)، وجـاءت نتائج تحليل التباين المشترك على النحو الذي يوضحه الجدول التالي: الجدول (v) (1) (1)

نتائج تحليل التباين المصاحب (ANCOVA) للفروق بين متوسطات تحصيل طلاب مجموعتي الدراسة على الاختبار التحصيلي الإجمالي البعدي

\begin{tabular}{|c|c|c|c|c|c|}
\hline مستوى الدلالة & قيمة (ف) المحسوبة & متوسط المربعات & درجات الحرية & مجموع المربعات & مصلدر التباين \\
\hline$\cdot, \wedge 09$ & •, & ร,マ^৭ & 1 & $\xi, \vee \wedge ৭$ & التحصيل القبلي \\
\hline \multirow[t]{3}{*}{$\cdot, \cdots 0$} & 1,9r7 & IrrA, 579 & 1 & IrrA, $\Sigma 79$ & الإستراتيجية \\
\hline & & I\&A,AYV & rq & OrOA,IIV & الخطأ \\
\hline & & & rA & $\eta r \cdot \cdot, r+\Lambda$ & المجهوع \\
\hline
\end{tabular}

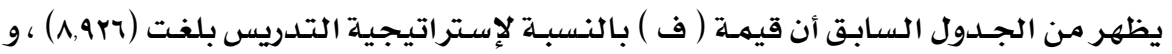

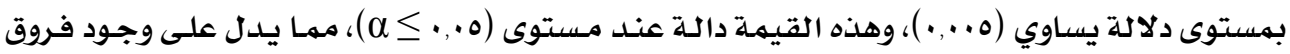

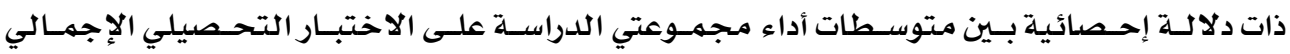

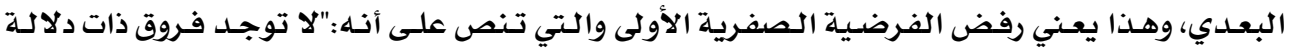

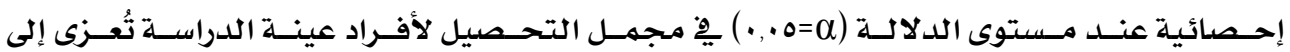
إسـتراتيـجية القـراءة التفـسيريـة بـاسـتخدام الوسـائط المتعـددة "، وتم اسـتخراج المتوسـطات الحسسابية المعدلة وتظهر النتائج ِِِ الجدول الآتي: 
مجلة بحوث التربية النوعية - عدد rr - أكتوبر ll ا.r- الجزء الثانسي

$$
\text { الجدول (ᄉ) }
$$

المتوسطات الحسـابية المعدلة والأخطاء المعياريـة لتحصيل طلاب مجموعتي الدراسـة على الاختبار التحصيلي الإجمالي البعدي باختلاف إستراتيجية التدريس

\begin{tabular}{|c|c|c|c|}
\hline الخطأ المعياري & المتوسط الحسابي & العلدد & المجموعة \\
\hline$r, r r$ & rr, rq & r. & التجريبية \\
\hline$r, \wedge_{\bullet}$ & $71, v$. & 19 & الضابطة \\
\hline
\end{tabular}

يلاحظ من الجلدول السـابق أنّ المتوسط الحسـابي المعـدل للمهجموعـة التجريبيـة الـتي تعلمهت

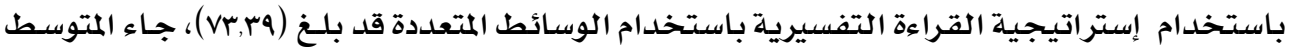

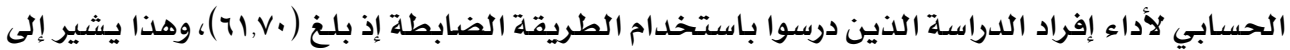
أن الفـرق كـان لــالح المجموعـة التجريبيـة التي تعلهـت باسـتخدام إسـتراتيـية القـراءة التفسسيرية

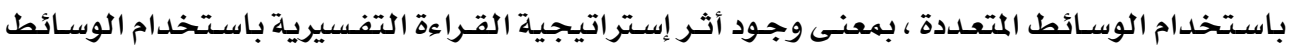
المتعددة فِ مجهل التحصيل لأفراد عينـة الدراسـة تُعزى إلى إستراتيحيـة القـراءة التفسيرية بـاستتخدام الوسـائط المتعددة.

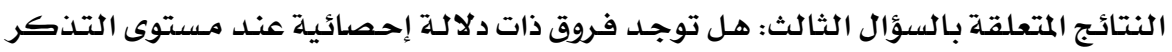

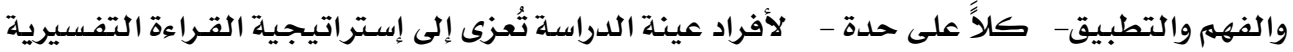
باستخدام الوسائط المتعددة ؟ من أجل الإجـابـة عن السؤال الثالث قام الباحث باستخراج المتوسطات الحسابية والانحرافات

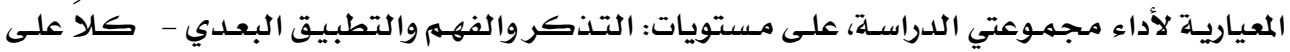

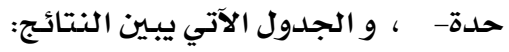
(9) (9) (9)

المتوسطات الحسابية والانحرافات المعياريـة لأداء مجموعتي الدراسـة على مستويـات: التذكر والفهم والتطبيق البعدي

\begin{tabular}{|c|c|c|c|c|}
\hline \multicolumn{2}{|c|}{ الاختبار البعلي } & \multirow{2}{*}{ العدد } & \multirow{2}{*}{ المجموعة } & \multirow{2}{*}{ المستوى } \\
\hline الانحراف المعياري & المتوسط الحسابي & & & \\
\hline 11,99 & $79,9$. & r. & التجريبية & \multirow{2}{*}{ التذكر } \\
\hline $19, \mathrm{VA}$ & or, 71 & 19 & الضابطة & \\
\hline $17, \leqslant 7$ & V乏, rA & $r \cdot$ & التجريبية & \multirow{2}{*}{ الفهي } \\
\hline IV,rr & $M r, O A$ & 19 & الضابطة & \\
\hline 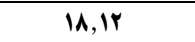 & 79,19 & $r \cdot$ & التجريبية & \multirow{2}{*}{ التطبيق } \\
\hline 11,90 & or, rA & 19 & الضابطة & \\
\hline
\end{tabular}

يتضـح من الجدول (و) أنّ المتوسط الحسسابي للمهجموعـة التجريبيـة التي تعلمـت باسـتخدام

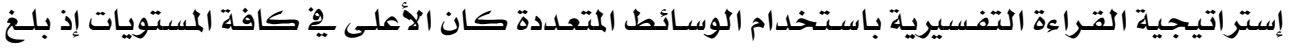




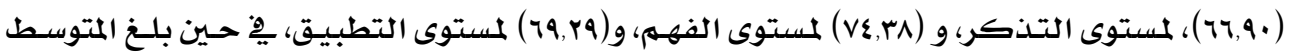

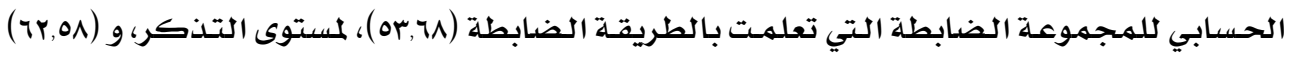

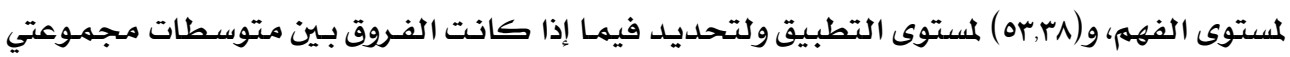

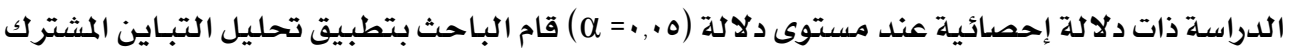

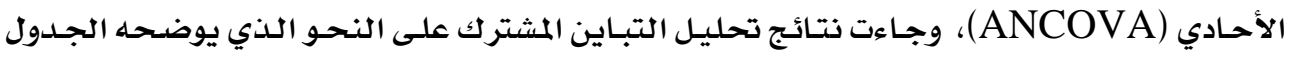
التالي:

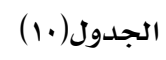

نتائج تحليل التباين المصاحب (ANCOVA) للفروق بين المتوسطات الحسابية لأداء مجموعتي الدراسة على الى مستويات: التذكروالفهم والتطبيق البعدي

\begin{tabular}{|c|c|c|c|c|c|c|}
\hline |مستوى الدلالة & | قيمة ف & متوسط مجموع المربعات & | درجات الحرية & | مجموع المربعات | & مصدر التباين & المستوى \\
\hline$*,+\xi$. & \&,Oro & $1.9 \%$, OrY & 1 & 1.9r, orv & الاختبار القبلي & \multirow{4}{*}{ التذكر } \\
\hline \multirow[t]{3}{*}{$\cdot, \cdot 10$} & $7,0 \wedge \xi$ & $10 A V, 091$ & 1 & $10 \wedge Y, 091$ & الإستراتيجية & \\
\hline & & $r \xi|| r \mid$, & $r q$ & $14 \lambda \cdot, r 7 q$ & الخطأ & \\
\hline & & & $r \Lambda$ & $11 \xi Y 0,79 r$ & المجموع & \\
\hline$\cdot, 1 \cdot \gamma$ & $r$, YTA & VET,qFI & 1 & $V \leqslant r, q H I$ & الاختبار القبلي & \multirow{4}{*}{ الفهه } \\
\hline \multirow[t]{3}{*}{$\cdot, \cdot r Y$} & $\xi, 791$ & $|r r|, \& q \mid$ & 1 & $|r r|, \& q \mid$ & الإستراتيجية & \\
\hline & & YYY, rMo & $r q$ & $9 \Lambda \cdot 0,17 \Lambda$ & الخطأ & \\
\hline & & & $r \Lambda$ & $119 . r, \wedge 09$ & المجموع & \\
\hline •, rro & 1, OrY & 017, AOr & 1 & $017, \wedge 0 \mathrm{~T}$ & الاختبار القبلي & \multirow{4}{*}{ التطبيق } \\
\hline \multirow[t]{3}{*}{$\bullet, \cdots 9$} & $v, 0 \leqslant v$ & rOO\&,YYY & 1 & rook,YTr & الإستراتيجية & \\
\hline & & $r r \Lambda,\{\& 0$ & rq & $|r| A\}, \bullet \cdot V$ & الغطأ & \\
\hline & & & $r \Lambda$ & $1017 \&$, ATO & المجموع & \\
\hline
\end{tabular}

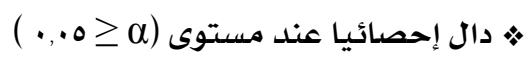

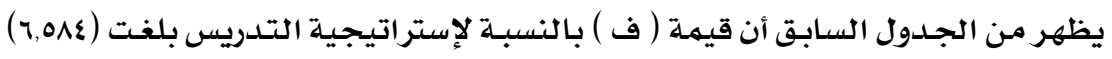

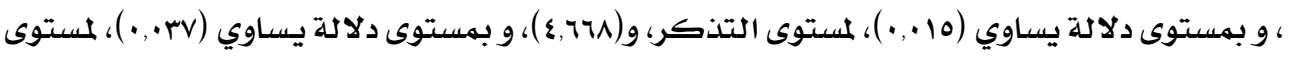

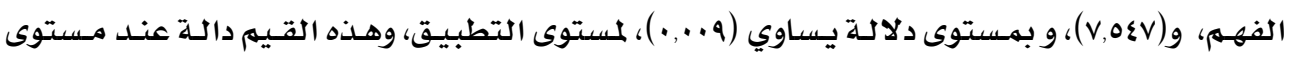

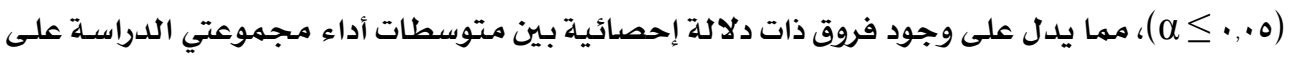

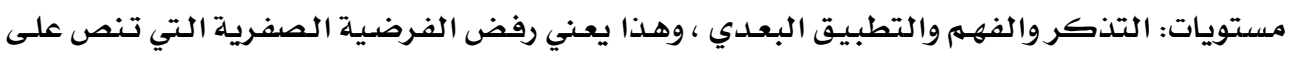

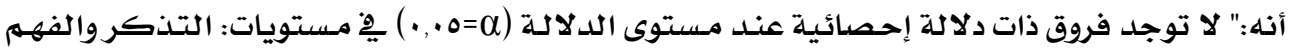

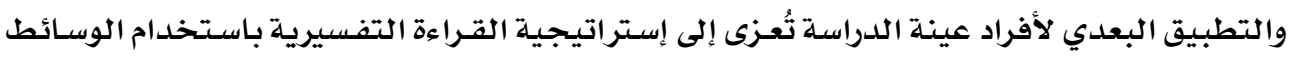

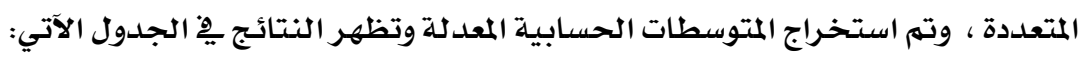


مجلة بحوث التربية النوعية - عدد rr - أكتوبر ll ا.r- الجزء الثانسي

(11) (11) (20)

المتوسطات الحسابية المعدلة والأخطاء المعيارية لتحصيل طلاب مجموعتي الدراسة على مستويات: التذكر والفهم والتطبيق البعدي باختلاف إستراتيجية التدريس

\begin{tabular}{|c|c|c|c|c|}
\hline الخطأ المعياري & المتوسط الحسابي & العلدد & المجهوعة & المستوى \\
\hline$r, \xi V$ & 77,79 & $r \cdot$ & التجريبية & \multirow{2}{*}{ التذكر } \\
\hline$r, 07$ & or, 91 & 19 & الضابطة & \\
\hline$r, 79$ & $V \xi, r$. & $r_{0}$ & التجريبية & \multirow{2}{*}{ الفهه } \\
\hline$r, v q$ & Tr,Vr & 19 & الضابطة & \\
\hline$\xi, I r$ & $79,8 \%$ & r. & التجريبية & \multirow{2}{*}{ لتطبيق } \\
\hline$\xi, Y r$ & Or, rr & 19 & الضابطة & \\
\hline
\end{tabular}

يلاحظ من الجلدول السـابق أنّ المتوسط الحسـابي المعـل للمهجموعـة التجريبيـة التتي تعلمست

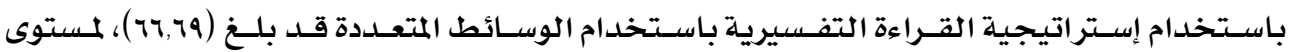

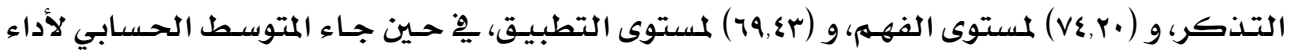

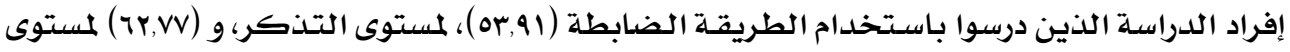

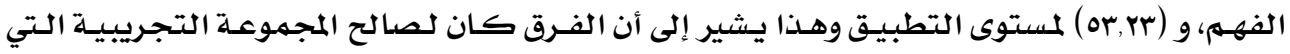

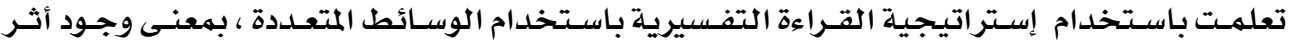
إستراتيجية القراءة التفسيرية باستخدام الوسـائط المتعددة ِِّ مستويات: التذكر والفهم والتطبيق لأفراد عينـة الدراسـة تُعزى إلى إستراتيـجية القراءة التفسيريـة بـاستخدام الوسـائط المتعددة.

\section{هناقشة النتائج والتوصئهات}

هدفت هذه الدراسـة إلى معرفة فاعليـة إسـتراتيـجيـة القـراءة التفسيريـة بـاسـتخدام الوسـائط

المتعددة يخ إتقان التلاوة والتحصيل لدى طلاب الصف السـادس الابتدائي يِّ تدريس وحسدة مـن القـرآن الكريهم وقد تم عرض النتائج التي توصلت إليها الدراسلة ، وفيما يأتي تفسير و مناقشة تلك النتائج : أولاً : النتأئج المتعلقة بالسؤال الأول: هل توجد فروق ذات دلالة إحصائية في إتقان التلاوة لأفراد عينة الدراسـة

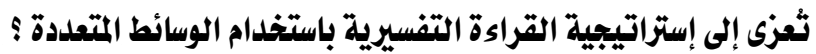

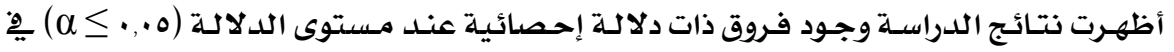

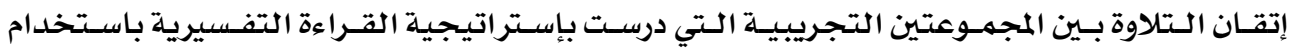
الوسائط المتعددة والضابطة التي درست بالطريقة التقليدية لصالح المجموعة التجريبية.

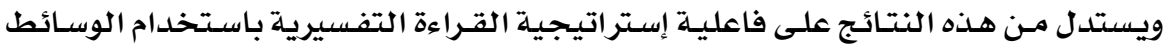
المتعددة يِّ إتقـان الـتلاوة وبهـكن أن يُعزى هـذا التفـوق إلى أن اسـتخدام الوسـائط المتعـددة يسـاعد على تقديه تفسير لكلآيات بصورة سهلة ومؤثرة ومبسطة تُؤدي إلى فهم واضح ودقيق للآيات مـن قبل الطلاب

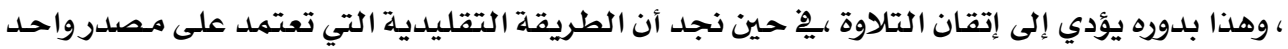


للمعرفـة وهو المعلسم لا يـتم فيهـا تقـديهم تفسير واضـح للآيـات أو شـرح للكلمـات أو الوقوف على العبر

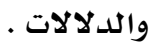

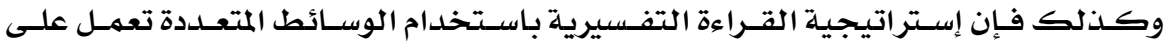

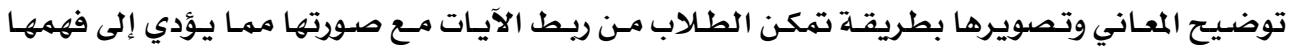
وإتقان تلاوتها.

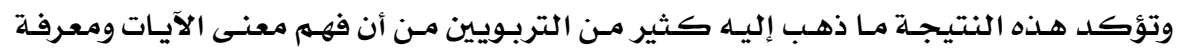

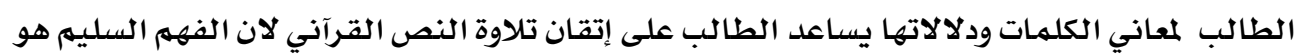
أساس الأداء الصحيح وتلاوة القرآن الكريهم وفهم معناه عمليتان متلازمتان الكان.

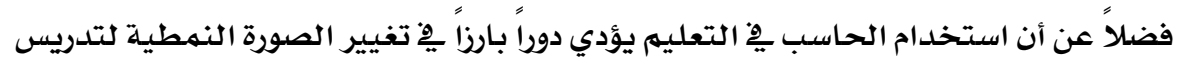

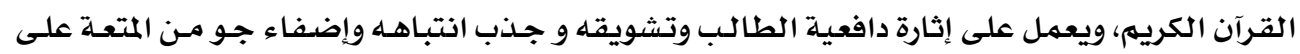

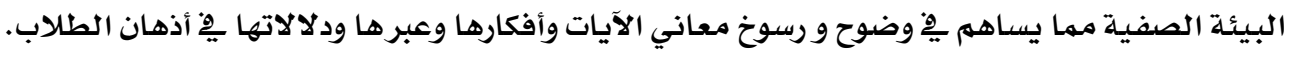

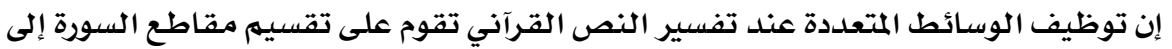

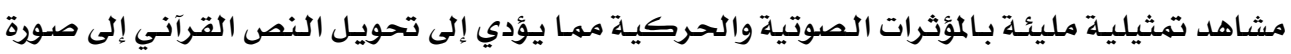

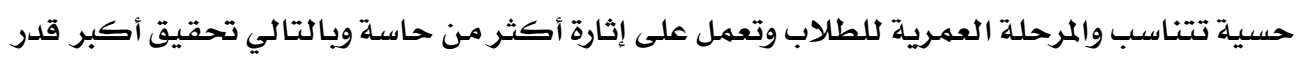

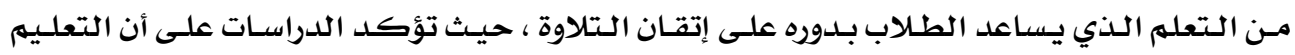

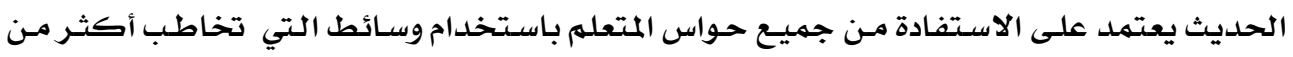

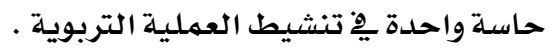
يضاف لذلك أن إتقان الطالب للههارات المعرفيـة والتي تتهم عن طريق إسـتراتيجية القـراءة

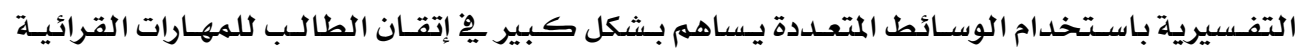
والمتمثلة بقراءة النص القرآني دون أخطاء. باء.

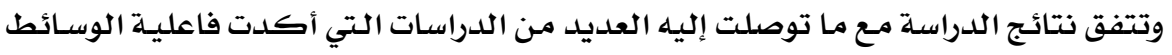

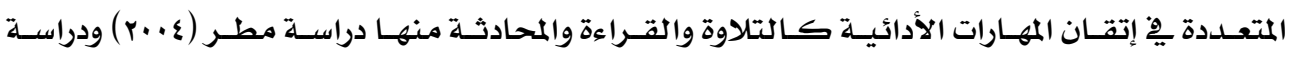

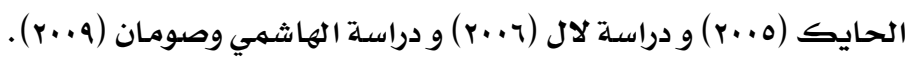
ثانياً : النتائج المتعلقة بالسؤال الثاني والثالث:

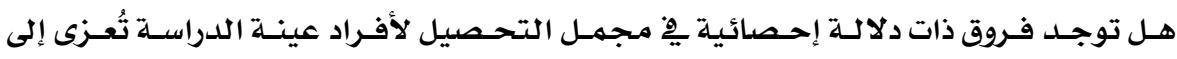

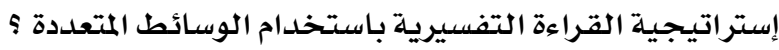

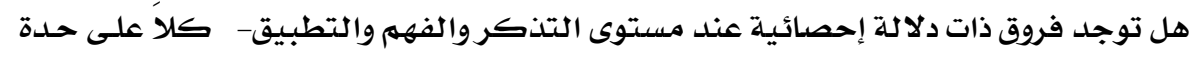

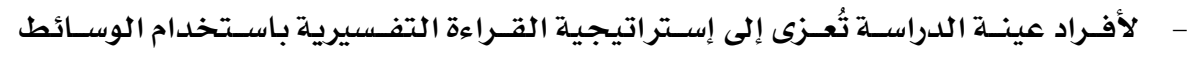

المتعددة ؟ - n

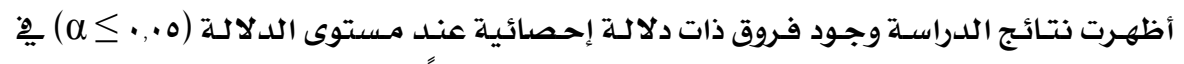

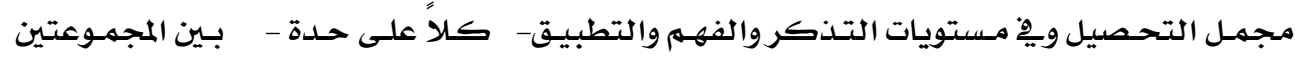




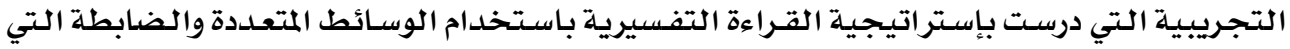
درست بالطريقة التقليدية لصالح المجموعة التجريبيـة. ويستــل مـن هـذه النتـائج على الأثر الإيجـابي لإســر اتيجيـة القـراءة التفسيرية باسـتخدام

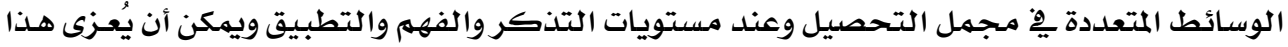

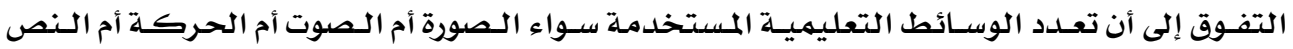
وغيرهـا مـن الوسـائط الحركيـة يـؤدي إلى تعـدد المثيرات الـتي تخاطـب العقـل مهـا يـؤدي إلى تقويــة الروابط العصبية يِّ الدماغ إذ أنه كلها تعددت المثيرات التعليميـية زادت قوة الـروابط العصبية وكلهـا زادت قوة الروابط العصبية اتسعت عمليات الفهم والاستيعاب والتحصيل والتذكر . يضـاف لـذلك مـا سـبق ذكـره عنــ تفسسير نتيجسـة السؤال الأول مـن أن توظيـف الوسـائط المتعددة عند تفسير النص القرآني يؤدي إلى تحويل النص القرآني إلى صسورة حسية تتناسـب والمرحلـة

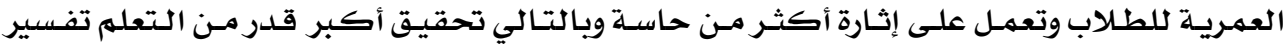
كلآيات بصورة سهلة ومؤثرة ومبسطة تُؤدي إلى فهم واضح ودقيق للآيات من قبل الطلاب مها يؤدي إلى زيـادة التحـصيل ويـسهل عمليـات الاسـتبقاء والتـذكر،وكلهما كانت صـورة الـنص القرآني مكتملـة ومـترابطــة وغـير مـتـاخلـهة كـان التحـصيل لهـا اكـبر وتـذكرها واسـترجاعها أسـرع وهــا مـا تقـوم

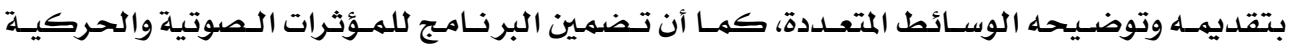

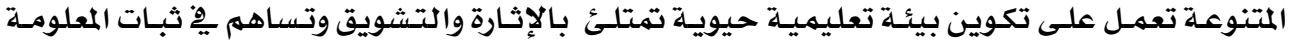
ورسوخها مهـا يؤدي إلى تفوق طلاب المجموعة التجريبيـة يخ الاختبـار التحصيلي البعـدي ، بينهـا نجـد

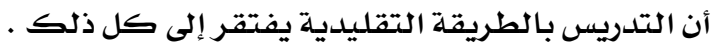

ويجب الإثـارة إلى سببـ آخر أدى إلى تفوق المجموعـة التجريبيـة وهـو أن توظيف إسـتراتيـيـية

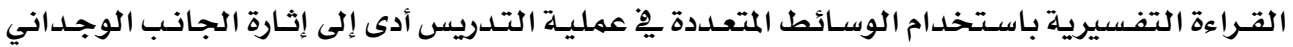

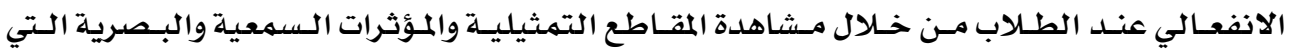
تضهنها البرنامـج وهذا يزيـ مـن تفاعلههم مـع النص القرآني وفهمهمه لمعانيـه وأفكاره وعبره ودلالاتـه وتأثرهم بـه وثبات المعارف التي اكتسبوهـا وقوة تذكرهم لها مها يؤدي إلى تحقيق نتائحج مـرتفعة على الاختبـار التحصيلي

ونظرا لان أثر القراءة التفسيرية تركز على المهارات المعرفية الثلاث الأولى من تصنيف بلـوم وهي التذكر والفهم والتطبيق فقد ظهرت الفروق بين المجموعتين يِ هذه المهارات الثلاث . وتتفق نتائج الدراسـة كذلك مـ مـا توصلت إليـه العديــ مـن الدراسـات الـتي أكـدت فاعليـة

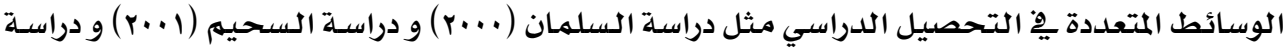

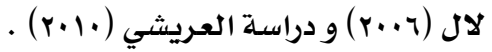




\section{في ضوي ما أسفرت عنه نتائج اللدراسة يقترح الباحث التوصيات الآتية :}

1) العمل على توظيف الوسائط المتعددة يِّ تدريس مقرر تلاوة القرآن الكريهم وحفظه وتفسيره

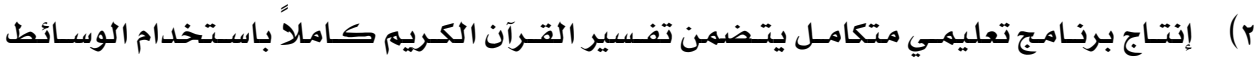

المتعددة يتلاءم مـع الخصائص العمرية لطلاب المرحلة الابتدائية والمتوسطة والثانوية . r) حث المعلمـين على إنتاج واستخدام البر مجيات التي توظف الوسائط المتعددة يِّ تدريس القرآن

الكريم.

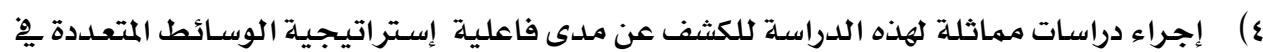

$$
\text { تدريس فروع العلوم الشرعية ويٌْ مختلف المراحل العمرية . }
$$

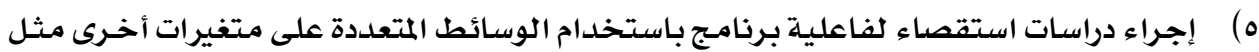
إتقان حفظ القرآن الكريم ب والتطبيق والتركيب مستويات التحصيل العليا من تصنيف بلوم

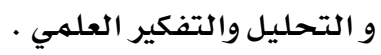

\section{قائمة المراجع أولاً: المراجع العربية}

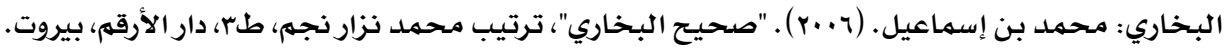

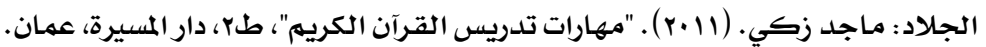

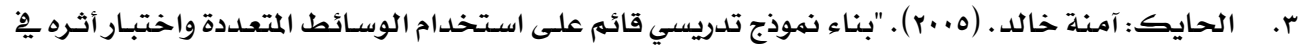

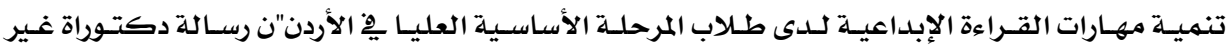
منشورة، جامعة عمان العربية - الأردن.

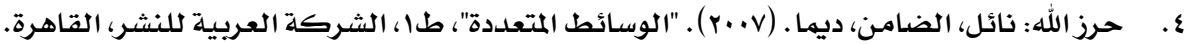

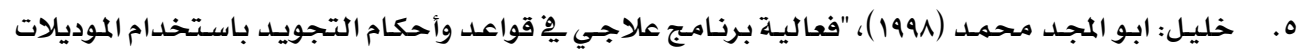

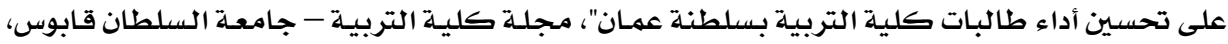

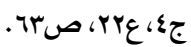

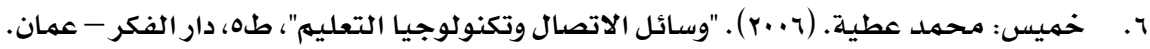

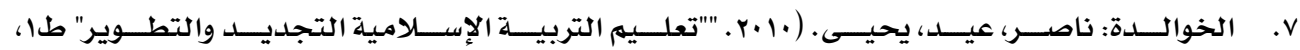
مكتبة الفلاح، الكويت.

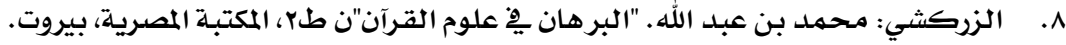

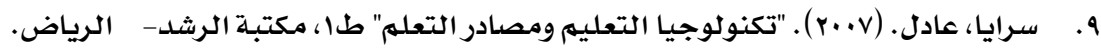




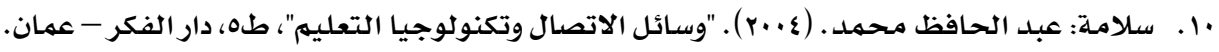

ال. الشافعي: إبراهيه محمد. (1919) . "التربية لا إسلامية وطرق تدريسها"، طب، دار الفلاح - الكويت.

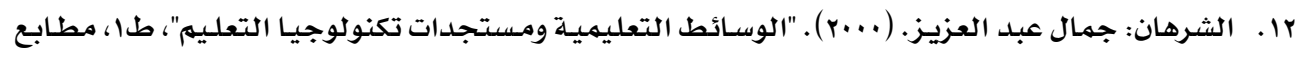
الحميضي - الرياض.

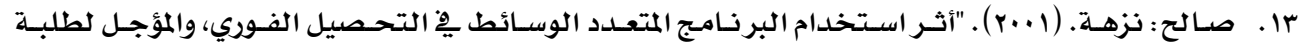
الصف التاسع الأساسي يِّ قواعد اللغة العربية"، رسـالة ماجستير غير منشورة، الجامعة الأردنية - عمان.

عا ـ صلاح: سمير يونس. (v. (r). الطرق التربوية تعليه الاحكام والقيهم القرآنية" طا، دار إقرأ الكويت.

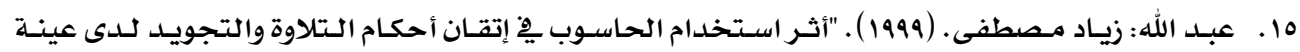
أردنية"، رسالة ماجستير غير منشورة، جامعة آل البيت - الأردن.

17 . عبد الله: عبد الرحمن صالح وآخرون. (199V) . "أساليب التدريس والتقويه"، طا، دار البشير - عمان.

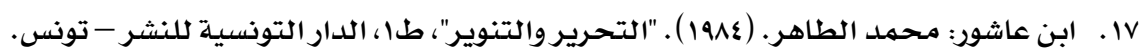

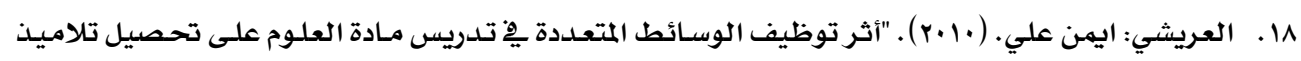
الصف السـادس الابتـدائي يِّ مدينـة جيـزان"، رسـالة ماجسستير غـير منـشورة، كليـة التربيـة - جـامعـة أم القرى، المملكة العربية السعودية.

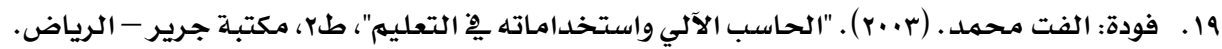
•r. . القاري: عبد العزيز عبد الفتاح. ( •191) . "التجويد والميسر" طب، دار الأرقم - الكويت.

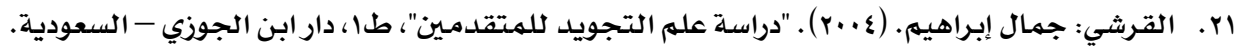
Yr. . القرضـاوي: يوسف. (1999) . "كيف نتعامل مـع القرآن العظيه" طا، دار الشروق - القاهرة. سץ. اللاحه: خالد عبد الكريه، "الحفظ التربوي للقرآن الكريه وصناعة الإنسـان"، طا، دار النشر، بـدون تـاريخ النشر، بـدون.

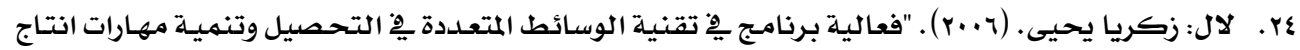

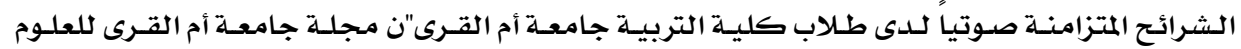

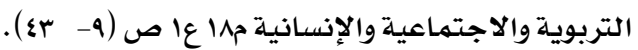

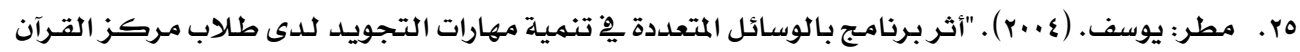
الكريهم بـالجامعة الإسلاميلة بغزة"، رسالة ماجستير غير منشورة، كلية التربية - الجامعة الإسلامية بغزة.

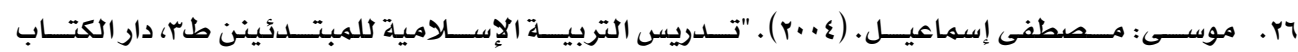

$$
\text { الجامعي - الإمارات. }
$$

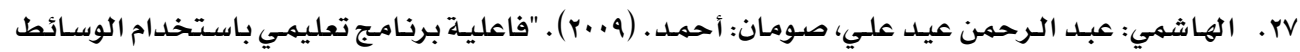

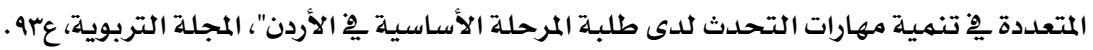

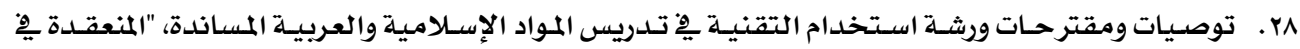

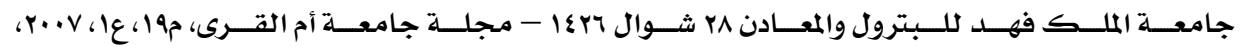
. 


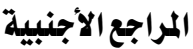

1. Davis Bernadetee and Shada Daniel (1999). Inter grating Technology Into the Early child hood class room the case of Literacy Learning Information Technology in child hood Education, 221-254.

2. Nikolova, O.R (2002). "Effect of students participation in Authering of multimedia materials on student Acquisition of Vocabulary, language learning \& Technology 6, 100-122.

3. Tway, L (1995). "Multimedia action, Boston AP Professional. Vaughan, T. (1994), "Multimedia: making it work, second Ed. N.Y. oborne Mc Graw Hill, 1 nc. 